\title{
Papers
}

\section{Recent sea surface temperature trends and future scenarios for the Mediterranean Sea}

doi:10.5697/oc.56-3.411

OCEANOLOGIA, 56 (3), 2014. pp. $411-443$.

(C) Copyright by Polish Academy of Sciences, Institute of Oceanology, 2014.

KEYWORDS

Mediterranean Sea Sea surface temperature

Climate change Heat exchange Total cloud cover

\author{
Mohamed Shaltout ${ }^{1,2 \star}$ \\ Anders OMstedT ${ }^{2}$ \\ 1 Faculty of Science, \\ Department of Oceanography, \\ University of Alexandria, \\ Alexandria, Egypt; \\ e-mail: mohamed.shaltout@gvc.gu.se \\ ${ }^{\star}$ corresponding author \\ ${ }^{2}$ Department of Earth Sciences, \\ University of Gothenburg, \\ P.O. Box 460, Göteborg 40530, Sweden
}

Received 13 May 2013, revised 25 November 2013, accepted 23 January 2014.

\begin{abstract}
We analyse recent Mediterranean Sea surface temperatures (SSTs) and their response to global change using 1/4-degree gridded advanced very-high-resolution radiometer (AVHRR) daily SST data, 1982-2012. These data indicate significant annual warming (from $0.24^{\circ} \mathrm{C}$ decade $^{-1}$ west of the Strait of Gibraltar to $0.51^{\circ} \mathrm{C}$ decade $^{-1}$ over the Black Sea) and significant spatial variation in annual average SST (from $15^{\circ} \mathrm{C}$ over the Black Sea to $21^{\circ} \mathrm{C}$ over the Levantine sub-basin). Ensemble mean scenarios indicate that the study area SST may experience significant warming, peaking at $2.6^{\circ} \mathrm{C}$ century ${ }^{-1}$ in the Representative Concentration Pathways 85 (RCP85) scenario.
\end{abstract}

The complete text of the paper is available at http://www.iopan.gda.pl/oceanologia/ 


\section{Introduction}

The Mediterranean Sea and its surrounding sub-basins extend from $-9^{\circ}$ to $42^{\circ} \mathrm{E}$ and from $30^{\circ}$ to $47^{\circ} \mathrm{N}$ (Figure 1) and can be divided into several sub-basins, for example, the Active Atlantic Mediterranean subbasin (hereafter 'AAM sub-basin') west of the Strait of Gibraltar and the Black Sea, connected to the Aegean Sea by the Dardanelles Strait. The study area is economically important, being exploited for fisheries, oil and gas extraction, and offshore renewable energy; it is also used for shipping, which links its many harbours. In the coastal zone, tourism, road transportation and recreation are major uses. According to IPCC (2007) and Lionello et al. (2010), the study area is a climate change hotspot, especially vulnerable to the increased sea surface temperature (SST) caused by greenhouse gas emissions.

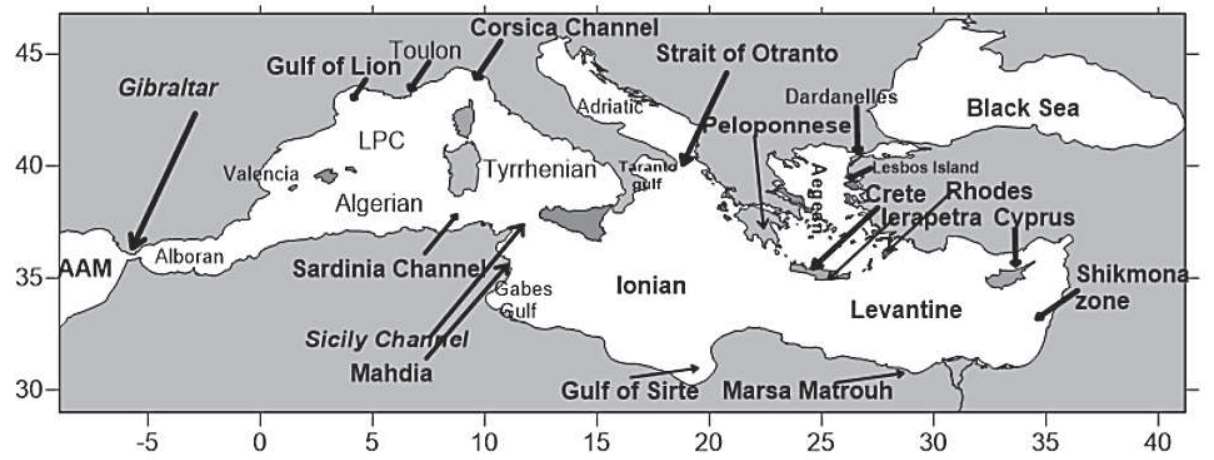

Figure 1. Geography of the Mediterranean Sea (LPC = the Liguro-Provencal and Catalan sub-basins, AAM = Active Atlantic Mediterranean sub-basin to the west of the Strait of Gibraltar)

Parada \& Canton (1998) found that 1993 satellite thermal images of the Alboran Sea indicated that the western Alboran anticyclonic gyre was an important feature; they also found seasonal SST variation over the Alboran Sea. Marullo et al. (1999) stated that the eastern Mediterranean SST is defined by two extreme distribution patterns, i.e. winter (zonal) and summer (meridional) patterns, with a transition period between them. They also identified permanent SST features in the eastern Mediterranean Sea (e.g. the Cretan Cyclone and Pelops Anticyclone). Their analysis was based on advanced very-high-resolution radiometer (AVHRR) weekly data with a spatial resolution of $18 \mathrm{~km}$. Leitz (1999) demonstrated that the Ionian Sea is characterised by strong seasonal variability with a mesoscale structure. Skliris et al. (2011) stated that the Aegean SST clearly increased 
southwards, partly due to exchange with cold Black Sea water through the Dardanelles Strait and with warm Levantine water through the Cretan Arc Straits.

D'Ortenzio et al. (2000) analysed AVHRR SST data from 1985 to 1996 and found no significant trend in the Mediterranean SST. Based on in situ observations, Lelieveld et al. (2002) claimed that the Mediterranean SST had cooled significantly from 1970 to 1980 and then warmed significantly

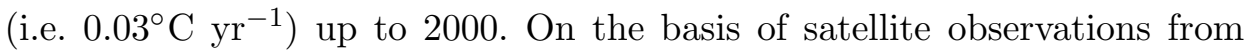
1985 to 2006, Nykjaer (2009) claimed that the Mediterranean SST had warmed by a significant 0.03 and $0.05^{\circ} \mathrm{C} \mathrm{yr}^{-1}$ in the western and eastern Mediterranean sub-basins, respectively, most markedly in June and in the Tyrrhenian sub-basin. Skliris et al. (2011) demonstrated that the Aegean SST displayed a general annual warming trend of $0.045^{\circ} \mathrm{C} \mathrm{yr}^{-1}$ over the 1985-2008 period, especially in summer $\left(0.045^{\circ} \mathrm{C} \mathrm{yr}^{-1}\right)$. Skliris et al. (2012) stated that the whole Mediterranean Sea displayed a significant warming trend of $0.037^{\circ} \mathrm{C} \mathrm{yr}^{-1}$ from 1985 to 2008 , especially in the eastern Mediterranean Sea. However, the warming trend in the Black Sea was much more marked: Ginzburg et al. (2004) noted significant SST warming (i.e. $0.09^{\circ} \mathrm{C} \mathrm{yr}^{-1}$ ) there from 1980 to 2000 , as indicated by night-time satellite observations, while satellite SST data indicated significant warming $\left(0.06^{\circ} \mathrm{C} \mathrm{yr}^{-1}\right)$ from 1982 to 2002 (Belkin 2009).

Tsimplis \& Rixen (2002), Luterbacher et al. (2004) and Skliris et al. (2011) demonstrated that the eastern Mediterranean SST is negatively correlated with the North Atlantic Oscillation Index (NAOI), which potentially affects water transport over the western Mediterranean Sea (Rixen et al. 2005). In addition, Skliris et al. (2012) noted a low (high) significant correlation between the Mediterranean SST and NAOI at the annual (decadal) scale from 1985 to 2008. Brierley \& Fedorov (2010) demonstrated that mid-latitude SST variability is affected by precipitation and global radiative forcing (e.g. water vapour and total cloud cover). Moreover, Skliris et al. (2012) claimed that Mediterranean SST spatiotemporal variability is significantly affected by increasing warming from Atlantic inflow. In general, wind forcing has significantly affected the Mediterranean SST, especially in the northern Adriatic Sea (Bora winds; Ferrarese et al. 2009), Aegean Sea (Etesian winds; Metaxas \& Bartzokas 1994), LPC sub-basin (Mistral winds; Jiang et al. 2003) and Alboran Sea (the Levanter and Vendaval winds; Anonymous 1988). LPC sub-basin refers to the Liguro-Provencal and Catalan sub-basins. The Mediterranean SST has also been linked to sea level pressure (Jung et al. 2006). Determining the correlations between the above-mentioned parameters and SST is an aim of the present work. 
Using a high-resolution ocean model forced by the A2 climate scenario, Somot et al. (2006) projected that the Mediterranean SST would increase by $3.1^{\circ} \mathrm{C}$ over the $1961-2099$ period. Using climate scenarios B1, A1B, and A2, Parry et al. (2007) projected that the global SST would rise by 1.5, 2.2, and $2.6^{\circ} \mathrm{C}$, respectively, during the 21 st century.

In late 2008, a new climate experiment was conducted involving coordinated climate models and 20 groups of climate modellers. The Coupled Model Intercomparison Project, phase five (CMIP5), included four new climate scenarios, i.e. RCP26, RCP45, RCP60 and RCP85, for the 21st century; RCP stands for 'representative concentration pathways' and the following number indicates ten times the radiative forcing at the end of the 21st century. The RCP26 scenario incorporates peak radiative forcing of $\sim 3 \mathrm{~W} \mathrm{~m}^{-2}\left(\sim 490 \mathrm{ppm} \mathrm{CO}_{2}\right)$ before 2100 , followed by declines to $2.6 \mathrm{~W} \mathrm{~m}^{-2}$ by 2100 (Van Vuuren et al. 2007). The radiative forcing in 2100 is approximately $3 \mathrm{~W} \mathrm{~m}^{-2}\left(\sim 490 \mathrm{ppm} \mathrm{CO}_{2}\right)$ in the RCP45 scenario (Clarke et al. 2007), approximately $6 \mathrm{~W} \mathrm{~m}^{-2}\left(\sim 850 \mathrm{ppm} \mathrm{CO}_{2}\right)$ in the RCP60 scenario (Fujino et al. 2006) and approximately $8.5 \mathrm{~W} \mathrm{~m}^{-2}$ $\left(\sim 1370 \mathrm{ppm} \mathrm{CO}_{2}\right)$ in the RCP85 scenario (Riahi et al. 2007). The present study examines the response of the Mediterranean SST to global climate change in these four scenarios. According to Taylor et al. (2012), the CMIP5 scenarios are intended to improve on the success of the earlier CMIP phases. The CMIP scenarios address most of the World Climate Research Programme's (WCRP) component properties and suggestions.

Spatiotemporal SST variability over the Mediterranean Sea was further studied for the period ending 2008 (e.g. Skliris et al. 2012); the present study expands on this work, analysing spatiotemporal SST variability up to 2012. Similarly, the effects of atmospheric parameters on Mediterranean SST variability were further studied for the period ending 2008. The current paper extends examination of the effects of atmospheric components on Mediterranean SST variability up to 2012. In addition, the projected Mediterranean SST, which still needs attention, is analysed in the present study.

The present research uses a 31-year high-resolution SST database: 1) to examine temporal and spatial SST variability over the Mediterranean Sea and its surrounding sub-basins; 2) to analyse the relationship between the study area SST and other atmospheric parameters, such as NAOI, mean sea level pressure (SLP), precipitation (P), total cloud cover (TCC), wind stress components at $10 \mathrm{~m}$ above sea level (i.e. eastward wind stress $\tau_{a x}$ and northward wind stress $\tau_{a y}$ ), air temperature at $2 \mathrm{~m}$ above sea level (T2m) and air-sea heat fluxes; 3) to examine SST characteristics in the different sub-basins by dividing the study area into 10 sub-basins; and 4) to examine 
the projected SST in the study area up to 2100 using the ensemble mean of the most recent projection scenarios. The materials and methods used are presented in section 2 , the results in section 3 , and the discussion and conclusions in section 4 .

\section{Material and methods}

When analysing the recent characteristics and future uncertainty of SST in the present work, several data sources were used:

1) Gridded daily AVHRR data (version 2 ) with a $0.25^{\circ}$ latitude/longitude spatial grid for 1982-2012 (http://www.ncdc.noaa.gov/oa/climate/ research/sst/griddata.php) were used to study recent SST characteristics.

2) Daily NAOI data captured by the KNMI Climate Explorer (http:// climexp.knmi.nl) were used to study the link between NAOI and the study area SST.

3) Gridded daily data, 1982-2012, on several surface meteorological parameters and air-sea heat fluxes were extracted from the ERAInterim full-resolution $\left(0.75 \times 0.75^{\circ}\right)$ database (http://data-portal. ecmwf.int); these data were correlated with SST data to study the effects on SST dynamic variability.

4) Gridded CMIP5 ensemble means for various 21st-century scenarios (i.e. RCP26, RCP45, RCP60 and RCP85) with a spatial resolution of $1.25 \times 1.25^{\circ}$ (http://climexp.knmi.nl); these data were used to study future uncertainty in the study area SST.

These databases were extracted and compiled in order to study current and future trends and uncertainties. AVHRR SST data constitute an effective tool for studying the Mediterranean SST with a bias of less than $0.1^{\circ} \mathrm{C}$ (Marullo et al. 2007), and the ERA-Interim full-resolution data are in good agreement with observations (Berrisford et al. 2011, Shaltout et al. 2013). Moreover, the CMIP5 experiment provides significant tools for studying 21st-century uncertainty (Taylor et al. 2012).

\subsection{Recent Mediterranean climate characteristics}

The spatial and temporal distributions of the Mediterranean SST obtained from AVHRR data are studied by analysing the seasonal and interannual geographical and climatological distributions of averages and trends. The spatial and temporal resolutions of the SST data used are sufficient to examine seasonal and interannual variability (Nykjaer 2009). Seasonal (interannual) climatology is calculated by constructing seasonal 
(annual) averages for each grid for the studied 31-year period. Daily, seasonal and annual SST linear trends are calculated for each grid, each sub-basin and the entire study area. Ordinary least squares estimation was used to calculate linear trends. The amplitude and phase angle of the annual SST cycle (i.e. the most significant Mediterranean SST cycle; Marullo et al. 1999) were calculated for each grid in order to study the seasonality and time lag over the whole study area. The daily SST relative to each grid $(i, j)$ was analysed using Fourier analyses of a periodic function:

$$
f_{i, j}(t)=a_{i, j} \cos \left(\frac{2 \pi t}{T}\right)+b_{i, j} \sin \left(\frac{2 \pi t}{T}\right)=A \cos \left(\frac{2 \pi t}{T}+\vartheta_{i, j}\right),
$$

where $a$ and $b$ are the Fourier coefficients, $T$ is the one-year period, $t$ is the time,

$$
A=\text { Amplitude }=\sqrt{a^{2}+b^{2}}, \quad \vartheta=\tan ^{-1}\left(\frac{b}{a}\right) .
$$

The coefficient of variation (COV) for each grid is calculated as $\left(100 \times \frac{\text { standard deviation }}{\text { mean }}\right)$ to evaluate seasonal and interannual SST stability, which increases with decreasing $\mathrm{COV}$ for each grid. The monthly and interannual effects of various atmospheric parameters, i.e. NAOI, SLP, P, TCC, $\tau_{a x}, \tau_{a y}$ and T2m, and of air-sea heat fluxes on SST variability are studied using the correlation coefficient $(R)$ and number of observations $(n)$. All correlation coefficients have been tested for significance at the $95 \%$ level; however, the $t$-test is used to examine the significance (at 95\%) of all the linear trends.

$\tau_{a x}$ and $\tau_{a y}$ are calculated using a standard bulk formula:

$$
\tau_{a x}=\rho_{a} C_{D} U W, \quad \tau_{a y}=\rho_{a} C_{D} V W,
$$

where $\rho_{a}\left(1.3 \mathrm{~kg} \mathrm{~m}^{-3}\right)$ is the air density, $C_{D}$ is the air drag coefficient, $U$ and $V$ are the wind components in the $x$ and $y$ directions, respectively, and $W$ is the wind speed. The air drag coefficient is calculated in its non-linear form (Large \& Pond 1981), modified for low wind speeds as in Trenberth et al. (1990):

$$
\begin{array}{lll}
C_{D}=0.00218 & \text { for } & W \leq 1 \mathrm{~m} \mathrm{~s}^{-1}, \\
C_{D}=(0.62+1.56 / W) 0.001 & \text { for } & 1 \mathrm{~m} \mathrm{~s}^{-1}<W \leq 3 \mathrm{~m} \mathrm{~s}^{-1}, \\
C_{D}=0.00114 & \text { for } & 3 \mathrm{~m} \mathrm{~s}^{-1}<W \leq 10 \mathrm{~m} \mathrm{~s}^{-1}, \\
C_{D}=(0.49+0.065 W) 0.001 & \text { for } & W>10 \mathrm{~m} \mathrm{~s}^{-1} .
\end{array}
$$


Following, for example, Omstedt (2011), air-sea heat fluxes can be expressed by the net heat loss from the sea $F_{n}$ and solar radiation to the open water surface $F_{s}^{o}$, where $F_{n}$ is the sum of sensible heat flux $\left(F_{h}\right)$, latent heat flux $\left(F_{e}\right)$ and net long-wave radiation $\left(F_{l}\right)$.

The study area is treated as 10 sub-basins. The Mediterranean Sea is divided into eight sub-basins, i.e. the Alboran, Algerian, Tyrrhenian, LPC, Ionian, Levantine, Aegean and Adriatic sub-basins, together with the Black Sea and the AAM sub-basin.

\subsection{Climate projection for the 21st century}

The SST results obtained using the ensemble mean of the four CMIP5 future scenarios for the 2000-2012 period together with historical CMIP5 results for the 1982-1999 period were tested using AVHRR SST data. Direct monthly and annual biases (i.e. CMIP 5 ensemble mean minus AVHRR) were used to evaluate the accuracy of the CMIP5 over the 1982-2012 period.

The CMIP 5 ensemble mean was calculated based on 24 global climate models computed at KNMI (http://climexp.knmi.nl/select.cgi). The 30year running average SST over the 21st century was calculated to illustrate future trends and uncertainties based on the four CMIP5 scenarios used. This evaluates the most important factor affecting the projected SST at the end of this century, including its seasonal, regional and emissions variations.

\section{Results}

\subsection{Spatial and temporal distribution of the Mediterranean Sea surface temperature}

The Mediterranean SST and the seasonal and annual climatologyaveraged SST of the Mediterranean's adjacent regions will be used to describe the SST dynamics. The annual average Mediterranean SST is calculated to be $19.7 \pm 1.3^{\circ} \mathrm{C}$ (Figure 2a). The much warmer water, calculated on the basis of two standard deviations from the mean $\left(>22.4^{\circ} \mathrm{C}\right)$, occurred over only $0.4 \%$ of the Mediterranean Sea, especially to the east of the Levantine sub-basin. The much colder area $\left(<17.1^{\circ} \mathrm{C}\right)$ occurred over only $2.8 \%$ of the Mediterranean Sea, especially in the Gulf of Lion and in the north of the northern Adriatic sub-basin. The annual average zonal SST gradient over most of the Mediterranean Sea increases from north to south, except over the northern Tyrrhenian and the Levantine sub-basins (meridional gradient), where it increases from west to east, partly due to the Mediterranean surface circulation. Moreover, the annual average SST 

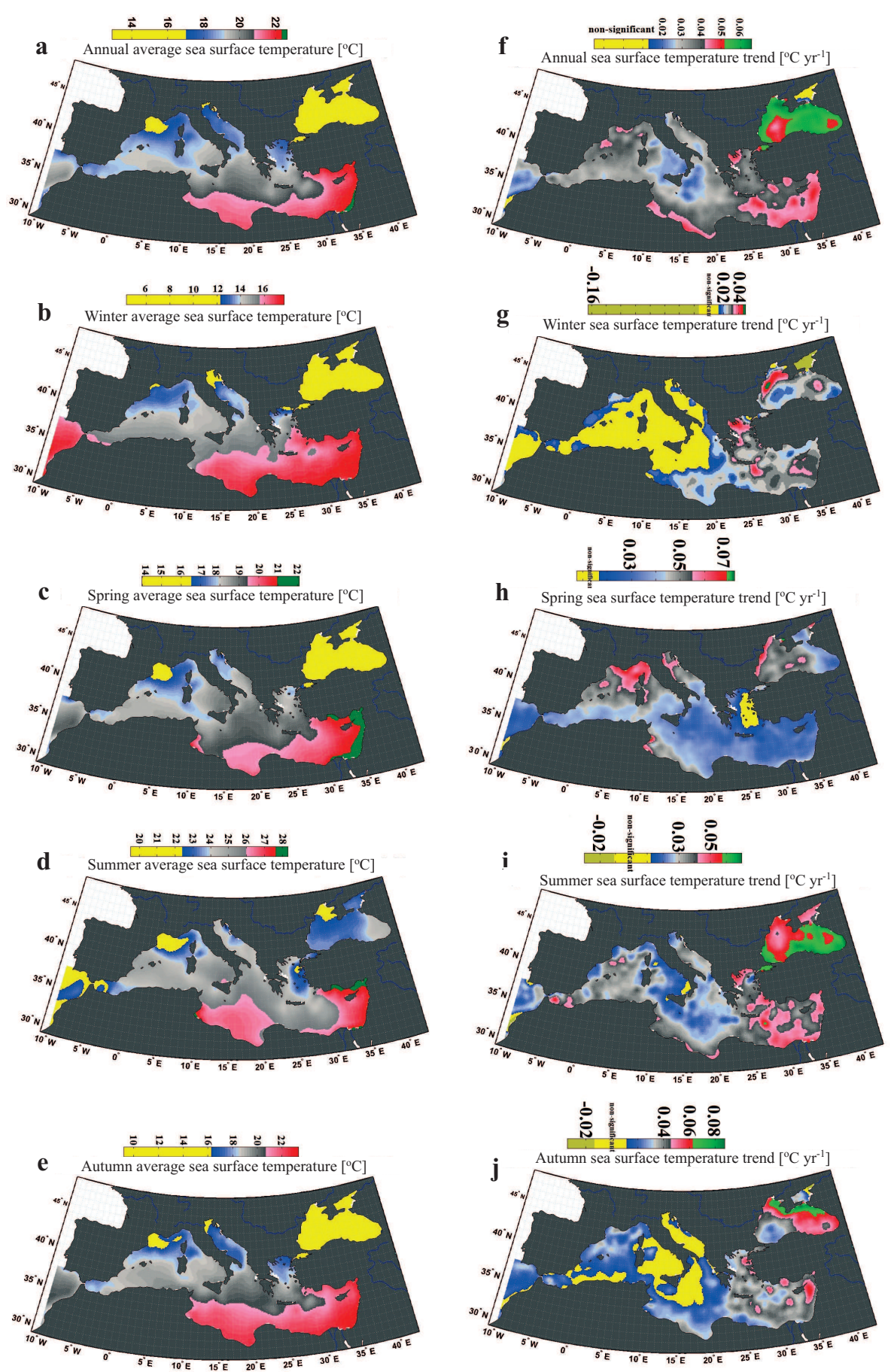

Figure 2. Spatial distribution of annual/seasonal SST means and trends over the 1982-2012 period; green in the left (right) panels (continued on next page) 
(Figure 2, continued) indicates much warmer areas (strong warming trend) of the Mediterranean Sea, while yellow represents much colder areas (non-significant warming trend) of the Mediterranean Sea; much colder/warmer areas are calculated on the basis of mean \pm two standard deviations

in the Aegean sub-basin is much lower than in the northern Ionian subbasin, which is at the same latitude, partly due to water exchange with the colder Black Sea. This indication supports the previous findings that the water exchange between the eastern Mediterranean and Black Seas controls the eastern Mediterranean heat balance (Shaltout \& Omstedt 2012). In addition, the annual average SST in the Alboran sub-basin is much lower than in the AAM sub-basin, which is at the same latitude. Generally, the SSTs in the LPC and Algerian sub-basins are related, which may indicate surface water exchange between these two sub-basins. Poulain et al. (2012) support this indication, describing the surface exchange between the LPC and Algerian sub-basins. The spatial pattern of the Mediterranean SST differs significantly from season to season, being $9.7-17.7^{\circ} \mathrm{C}$ in winter, $15.8-$ $22.1^{\circ} \mathrm{C}$ in spring, $20.8-28.3^{\circ} \mathrm{C}$ in summer and $15.1-23.4^{\circ} \mathrm{C}$ in autumn.

The annual trend distribution of the Mediterranean SST (Figure 2f) indicates the presence of a warming trend throughout the Mediterranean Sea, ranging from $0.017^{\circ} \mathrm{C} \mathrm{yr}^{-1}$ (in the mid-western Ionian sub-basin) to $0.05^{\circ} \mathrm{C} \mathrm{yr}^{-1}$ (north-east of the Levantine sub-basin), with average values of $0.035 \pm 0.007^{\circ} \mathrm{C} \mathrm{yr}^{-1}$. There is a significant seasonal warming trend over the Mediterranean Sea, ranging from $0.016 \pm 0.001^{\circ} \mathrm{C} \mathrm{yr}^{-1}$ in winter to $0.038 \pm 0.109^{\circ} \mathrm{C} \mathrm{yr}^{-1}$ in spring. Similarly, the maximum warming trend

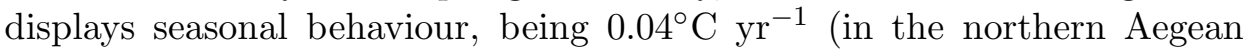
sub-basin and south-east of Crete) in winter, $0.067^{\circ} \mathrm{C} \mathrm{yr}^{-1}$ (off the coasts of Mahdia, Tunisia and of Toulon, France) in spring, $0.058^{\circ} \mathrm{C} \mathrm{yr}^{-1}$ (southeast of Crete) in summer, and $0.061^{\circ} \mathrm{C} \mathrm{yr}^{-1}$ (north-east of the Levantine sub-basin) in autumn.

The Adriatic sub-basin SST displayed seasonal behaviour (Figures 2be), increasing zonally from north to south in winter and autumn. The much colder northern Adriatic Sea can be explained by the effects of the Bora winds and the distance from the equator. The Bora winds, which are dry, cold and strong, blow intermittently over the Adriatic Sea from the NNE, NE, or ENE in winter (Ferrarese et al. 2009). Heat loss and evaporation are strongly coupled to the Bora winds, leading to dense water formation (Vilibić et al. 2004). In summer, the Adriatic sub-basin SST increased meridionally from east to west, with colder water upwelling along the eastern coast (Bakun \& Agostini 2001) and warmer water along the western coast. In the central Adriatic sub-basin in summer, cold filaments depart from the Croatian coast, heading offshore in the Adriatic Sea towards the Italian 
coast (Borzelli et al. 1999). This process partly normalises the meridional SST gradient, together with the moderating effect of the northern Adriatic sub-basin, and may explain why the SST is lower in the central than the northern Adriatic sub-basin in spring and summer. Moreover, the SST gradient over the southern Adriatic sub-basin increases meridionally from west $\left(18.2^{\circ} \mathrm{C}\right)$ to east $\left(18.9^{\circ} \mathrm{C}\right)$ in autumn. However, in the northern Adriatic sub-basin in autumn, the central part was much colder than the northern part owing to the moderating effect of the north part of the sub-basin.

The SST gradient over the Aegean sub-basin is significantly affected by water exchange, with cold/fresh Black Sea water entering through the Dardanelles Strait and warm/saline Levantine basin water entering through the Cretan Arc Straits. This is in agreement with the previous findings of Zervakis et al. (2000), Shaltout \& Omstedt (2012) and Poulain et al. (2012). The SST gradient displays a marked seasonal variability. In winter, the Aegean SST increases from the north-western part of the sub-basin $\left(13^{\circ} \mathrm{C}\right)$ to the south-east $\left(16.3^{\circ} \mathrm{C}\right)$. In spring and autumn, the Aegean SST decreases zonally from north to south, while in summer it displays a semicircular distribution centred near Lesbos Island $\left(22.2^{\circ} \mathrm{C}\right)$, where the SST increases with distance from the island. The much colder Aegean area occurs along the northern Aegean coast in cold seasons, then migrates south to the eastern part of the Dardanelles Strait in spring and farther south to Lesbos Island in summer. The Aegean SST is much lower than at the same latitude in the northern Ionian sub-basin, most markedly in summer, partly due to the Etesian winds. These winds are cold and dry (Metaxas \& Bartzokas 1994) and blow over the Aegean Sea in summer, north-easterly in the northern Aegean and northerly in the southern Aegean (Kotroni et al. 2001). The Etesian winds thus moderate the Aegean SST in summer. In summer, the Aegean SST is much lower than the higher latitude Adriatic sub-basin SST, partly due to the moderating effect of the cold and dry Etesian winds.

The Levantine sub-basin SST increases from north-west to south-east in autumn and winter, and increases meridionally from west to east in spring. In summer, however, the SST increases zonally from north to south over the eastern and meridionally from west to east over the western Levantine subbasin. The Cretan Cyclone south-east of the Cretan Passage is well defined in autumn and winter (cold core, $19^{\circ} \mathrm{C}$ in autumn and $15.2^{\circ} \mathrm{C}$ in winter) and influences the SST all the year round. The core of the Cretan Cyclone displays a less significant warming trend than does the surrounding area in winter, indicating the continuation and increasing intensity of the Cretan Cyclone, and hence of Levantine deep water formation, in future winters. However, the anticyclonic Pelops eddy (warm core, $16^{\circ} \mathrm{C}$ ) is well established in winter to the south-east of the Peloponnese (Greece), supporting the 
previous findings of Millot (2005) and Poulain et al. (2012). The core of the Pelops anticyclonic eddy (Figures $2 \mathrm{f}-\mathrm{j}$ ) displays insignificant warming relative to the surrounding area, indicating an insignificant change in the intensity of the Pelops eddy. Moreover, the grouping of eddies in the western Levantine basin (Millot 2005, Poulain et al. 2012) is less obvious, as there is only one anticyclonic eddy south of Crete in autumn (warm core, $21.8^{\circ} \mathrm{C}$ ). The core of this anticyclonic eddy displays more significant (insignificant) warming than does the surrounding area in summer, autumn and winter (spring), indicating the dominance of this eddy and suggesting that it may become more intense in the future. In addition, about three obvious anticyclonic eddies are attributable to the seasonal warming gradient over the western Levantine, especially in summer and autumn, indicating that the western Levantine eddies may become more significant in the near future. The eastern Levantine eddies (Poulain et al. 2012) are not obvious from the seasonal average SST gradient, as a $1 / 4^{\circ}$ projection grid was used. Poulain et al. (2012) described the eastern Levantine eddies using altimetry data with $1 / 8^{\circ}$ gridded resolutions. There is an obvious grouping of eddies in the eastern Levantine attributable to the seasonal warming gradient, especially in summer and autumn, indicating more intense eastern Levantine eddies in the future.

The Ionian sub-basin SST increases zonally from north (Gulf of Taranto) to south (west of Gulf of Sidra, Libya) in winter $\left(13.9-17.4^{\circ} \mathrm{C}\right)$ and autumn $\left(18.1-22.2^{\circ} \mathrm{C}\right)$, and from north-east $\left(24.2^{\circ} \mathrm{C}\right)$ to south-west $\left(28^{\circ} \mathrm{C}\right.$; Gulf of Gabes, Tunisia) in summer. In spring, however, the Ionian SST displays a mixed zonal and meridional gradient, ranging from $18.2^{\circ} \mathrm{C}$ off the north-western Ionian coast to $20.8^{\circ} \mathrm{C}$ in the Gulf of Gabes, Tunisia. Ionian mesoscale structures do not generally become more obvious with the seasonal SST increase, although the Ionian mesoscale eddies do become more obvious with the seasonal warming. The latter may indicate a significant increase in the intensity of Ionian mesoscale eddies in the near future. The Mid-Ionian Jet (Poulain et al. 2012) is generally obvious in the annual SST distribution (SST, $20.2^{\circ} \mathrm{C}$ ), most markedly in summer $\left(\mathrm{SST}, 25.5^{\circ} \mathrm{C}\right)$.

There is a significant difference in the SST gradient between the northern (meridional distribution) and southern (zonal distribution) Tyrrhenian sub-basin, partly due to the surface water circulation. The northern Tyrrhenian SST increases from north-east to south-west as follows: 13.6$14.6^{\circ} \mathrm{C}$ (winter), $17.6-19^{\circ} \mathrm{C}$ (spring), $23.2-26^{\circ} \mathrm{C}$ (summer), and $16.4-19.8^{\circ} \mathrm{C}$ (autumn). However, the southern Tyrrhenian SST increases zonally from south to north. The northern Tyrrhenian gyre (Poulain et al. 2012) is generally obvious to the east of Corsica in the annual SST distribution (core $\mathrm{SST}, 18^{\circ} \mathrm{C}$ ), most markedly in autumn (core SST, $16.8^{\circ} \mathrm{C}$ ). The distribution 
of the SST warming trend in autumn indicates that the core of the northern Tyrrhenian gyre is warming more significantly than is its surroundings. This may indicate that the northern Tyrrhenian gyre is a significant feature, especially in autumn.

The LPC sub-basin SST increases zonally from north (Gulf of Lion) to south in winter $\left(12-14^{\circ} \mathrm{C}\right)$ and autumn $\left(16-18.3^{\circ} \mathrm{C}\right)$. In spring and summer, the LPC sub-basin displays a semicircular SST pattern centred on the Gulf of Lion, where the SST is $16.2^{\circ} \mathrm{C}$ in spring and $22^{\circ} \mathrm{C}$ in summer; the SST increases with distance from the centre, the maximum SST occurring off the coast of Valencia, Spain, where it reaches $18.3^{\circ} \mathrm{C}$ in spring and $25.1^{\circ} \mathrm{C}$ in summer. There is a tongue of similar SST between the LPC and Algerian sub-basins; it is well established in spring, summer and autumn, partly reflecting surface water exchange between the two sub-basins. The Gulf of Lion represents the much colder SST over the entire Mediterranean Sea year, especially in summer, partly due to the effect of the Mistral winds. The Mistral winds are cold, dry and strong north or north-west winds affecting the western Mediterranean coast of south-eastern France (Jiang et al. 2003). In summer, the Mistral winds can rapidly lower the SST. Some significant warming trend eddies spatially distributed over the LPC sub-basin may indicate a potential change in LPC sub-basin water circulation in the near future.

The Algerian sub-basin SST increases zonally from north $\left(14^{\circ} \mathrm{C}\right)$ to south $\left(16^{\circ} \mathrm{C}\right)$ in winter. In spring (summer), approximately $80 \%(70 \%)$ of the Algerian sub-basin is in the $18-18.4^{\circ} \mathrm{C}\left(24.5-24.9^{\circ} \mathrm{C}\right)$ range. In autumn, approximately $50 \%(40 \%)$ of the Algerian sub-basin is in the $19.5-19.9^{\circ} \mathrm{C}$ $\left(18.6-19^{\circ} \mathrm{C}\right)$ range.

The Alboran sub-basin SST is significantly affected by the heat exchange with fresh Atlantic water through the Strait of Gibraltar, while the wind systems over the Alboran sub-basin significantly affect SST variability. The easterly Levanter warm wind is most common in summer, while the westerly Vendaval cold wind is most common in winter (Anonymous 1988). The SST over the Alboran Sea displays marked seasonal behaviour. The Alboran subbasin SST increases from the north-east $\left(15^{\circ} \mathrm{C}\right)$ to the south-west $\left(16^{\circ} \mathrm{C}\right)$ in winter, partly due to the Vendaval wind. In approximately $65 \%$ of the Alboran sub-basin, the SST lies in the $16-16.4^{\circ} \mathrm{C}$ range in autumn, increasing zonally from north to south and meridionally from west to east. The western Alboran anticyclonic gyre is well formed in summer, supporting the previous arguments of Millot (2005) and Poulain et al. (2012). The core of this gyre (Figures $2 \mathrm{f}-\mathrm{j}$ ) displays more significant warming than do the surrounding areas, most (least) markedly in summer (autumn). In spring and winter, the core of the western Alboran anticyclonic gyre displays 
a non-significant warming trend relative to the surrounding areas. This may indicate that the western Alboran anticyclonic gyre is a dominant feature and that its intensity will increase, especially in summer.

The Mediterranean SST is significantly affected by exchange with adjacent water basins (e.g. the Black Sea and the AAM sub-basin). The Black Sea is much colder than the Aegean sub-basin in all seasons. However, the Black Sea's warming trend is more significant than the Aegean Sea's warming trend. On the other hand, the Alboran sub-basin is much colder than the AAM sub-basin at the same latitude in all seasons except summer. However, the Alboran sub-basin's warming trend is more significant than the AAM sub-basin's warming trend all the year round, except in winter.

Fourier analysis of 31 years of daily resolved data indicates that the most significant SST cycle is the annual cycle. There is significant variability in the Mediterranean SST annual cycle (i.e. seasonality), which usually attains its maximum amplitude $\left(8^{\circ} \mathrm{C}\right)$ over the north Adriatic sub-basin and its minimum amplitude $\left(3^{\circ} \mathrm{C}\right)$ over the western Alboran sub-basin (Figure 3). The Black Sea SST seasonality is much more significant than the Mediterranean SST seasonality, while the AAM sub-basin SST seasonality is less significant than the Mediterranean SST seasonality (Figure 3). Moreover, the Mediterranean seasonality SST phase lag displays a zonal gradient ranging from a maximum value of 55 days over the northern Mediterranean (i.e. in the northern Adriatic) to a minimum value of 32 days over the southern Mediterranean (i.e. in the Gulf of Sidra, Libya). This may indicate a shift of seasonal timing in the northern versus the southern Mediterranean, because seasons come earlier in the north than the south. The annual seasonal phase lag of the Mediterranean SST closely follows the general Mediterranean surface circulation, indicating the importance of the general Mediterranean surface circulation for the SST distribution. In addition, there is a narrow passage of equal seasonal SST phase lag between the LPC and Algerian sub-basins, partly confirming the current

a

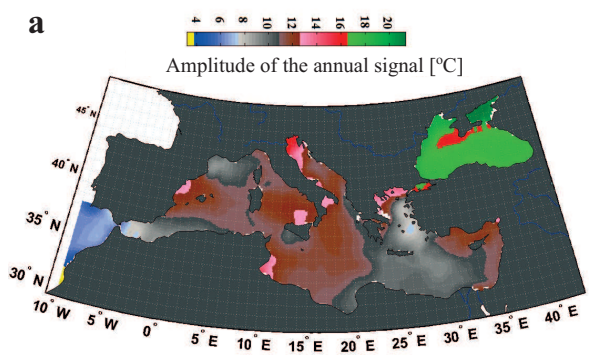

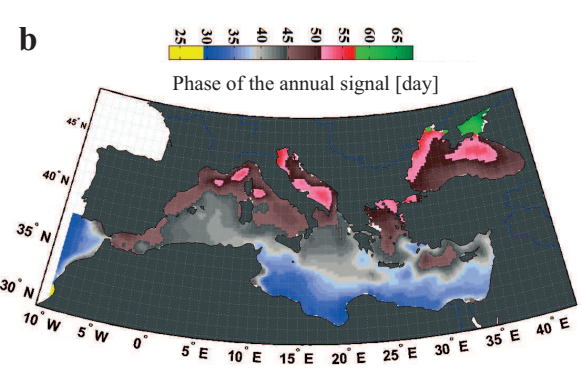

Figure 3. Spatial distribution of the amplitude (a) and phase (b) of the annual SST signal 
finding of the existence of surface exchange between both sub-basins through a narrow passage. The smallest spatial shift in SST seasonal phase lag (approximately 20 days) indicates that the cooling and warming forces affecting the Mediterranean Sea are in phase with the SST changes over the study area.

\subsection{Coefficient of variation (COV) of Mediterranean SST}

The coefficient of variation (COV) is used to examine the degree to which the SST varies around its mean value; SST variability increases with increased $\mathrm{COV}$ values.

The annual average COV of the Mediterranean SST (Figure 4) is $20.5 \pm 2.7 \%$, ranging from maximum stability $(4.8 \%)$ in summer and winter to minimum stability $(14.4 \%)$ in spring. The annual COV of the Mediterranean SST ranged between $13.1 \%$ in the eastern Alboran subbasin and $35.1 \%$ in the northern Aegean and Adriatic sub-basins. There is a marked seasonal variability in the COV of the Mediterranean SST (data not shown), i.e. winter $(3.4-14.4 \%)$, spring $(8.2-23.6 \%)$, summer (3.1-9.6\%) and autumn (8.3-19.3\%). The maximum seasonal stability of the Mediterranean SST occurred in the eastern Alboran sub-basin all the year round except in summer. In summer, the maximum seasonal stability occurred in the southern Levantine sub-basin. The minimum stability of the Mediterranean SST occurred in the northern Aegean and Adriatic subbasins in autumn, winter and spring; the minimum stability occurred in the Gulf of Lion and its surrounding area in summer.

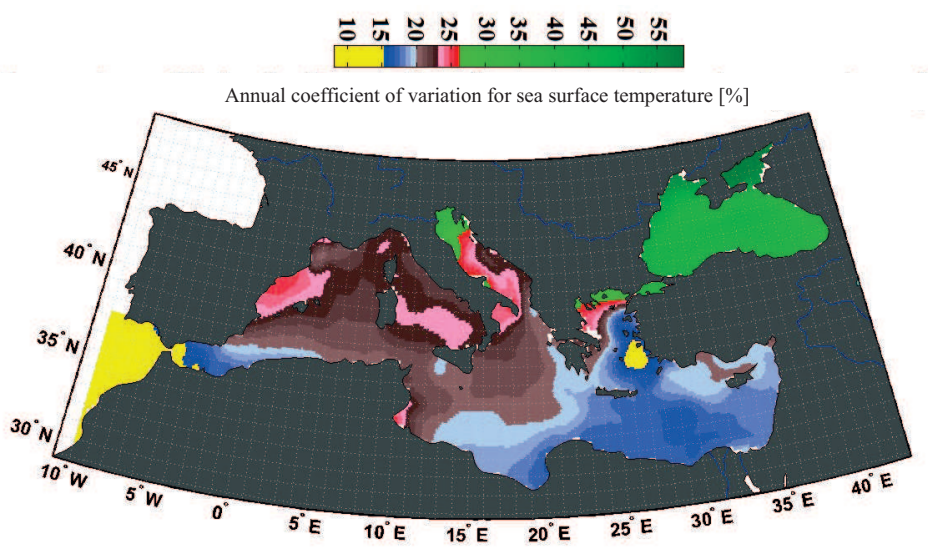

Figure 4. Spatial distribution of the annual coefficient of SST variation

The variability of the Black Sea SST (annual COV, $42.5 \%$ ) is twice that of the Mediterranean SST, indicating more extreme dynamics in the Black 
Sea, disproportionate to its relatively small area. However, the AAM subbasin SST is significantly less variable than is the Mediterranean SST.

The AAM sub-basin has two water masses: the source of the surface water mass is Atlantic Ocean surface water and that of the lower water mass is the Mediterranean outflow through the Strait of Gibraltar, which sinks rapidly in the AAM sub-basin to a depth of $1000 \mathrm{~m}$ (Delgado et al. 2001). Consequently, the AAM sub-basin SST is significantly affected by Atlantic water, which is characterised by low SST variability due to the Atlantic Ocean's large area. This may explain the low variability of the AAM subbasin SST.

\subsection{Correlation between the Mediterranean SST and the atmospheric parameters}

Based on monthly data, there is a significant negative correlation between SST and NAOI, most markedly over the eastern Black Sea and the eastern Levantine sub-basin in autumn (Figure 5 and Table 1).

Similarly, based on monthly data, there is a significant negative correlation between SST and the atmospheric parameters SLP, P and TCC, especially over the Levantine and Aegean sub-basins and in spring (Table 1 and Figure 5).

The maximum positive correlation between the effect of $\tau_{a x}$ on SST occurs over the Adriatic sub-basin $(R>0.54, n=372)$, while the maximum negative correlation occurs along the Algerian coast $(R<-0.5, n=372)$, as seen in Figure 5. However, the direct correlation between $\tau_{a y}$ and SST reaches its maximum positive level $(R>0.5, n=372)$ over the eastern LPC sub-basin and its maximum negative level over the western Levantine subbasin $(R<-0.5, n=372)$. The effects of $\tau_{a x}$ and $\tau_{a y}$ on the study area SST display seasonal behaviour, peaking in winter and autumn respectively. The monthly correlation between SST and T2m is high $(R>0.75, n=372)$ throughout the study area, most markedly $(R>0.98, n=372)$ over the central Ionian, Algerian and central Tyrrhenian sub-basins, and also over the southern Black Sea. The effect of T2m on SST is significant over $100 \%$ of the study area in all seasons except winter. In winter, the correlation between T2m and SST is significant over only $89 \%$ of the study area. This is in good agreement with the previous findings of Skliris et al. (2012). Skliris et al. (2011) demonstrated that T2m is highly correlated with the Mediterranean SST $(R=0.86$, level of significance $=99 \%)$.

Net heat loss from the sea $\left(F_{n}\right)$ is highly negatively correlated with SST $(R<-0.35, n=372)$ over the Adriatic and Aegean sub-basins (Figure 5h). However, the maximum positive correlation between $F_{s}^{o}$ and SST $(R>0.6$, $n=372$ ) occurs over the Adriatic and Aegean sub-basins and the Black Sea. 
a

Monthly correlation coefficient between Mediterranean SST and NAOI b

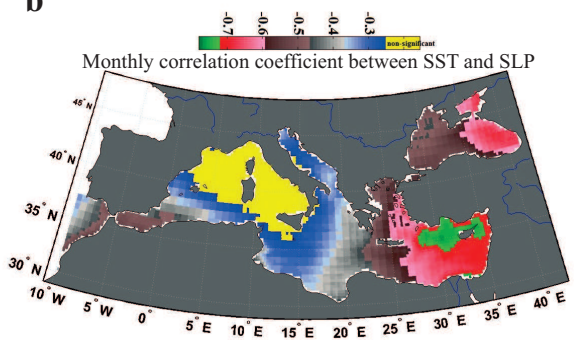

d
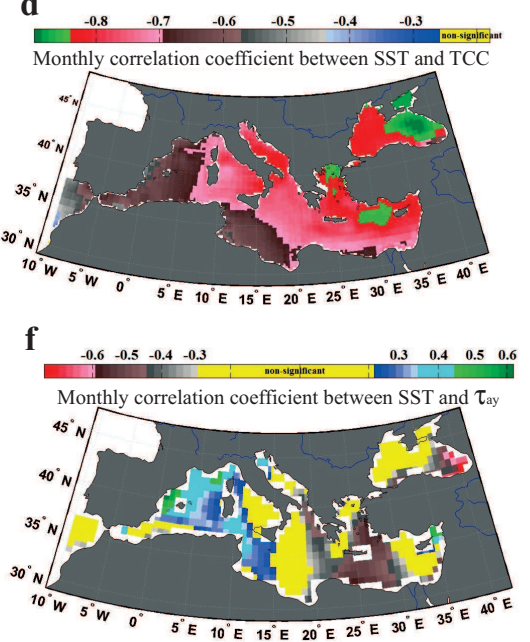

h

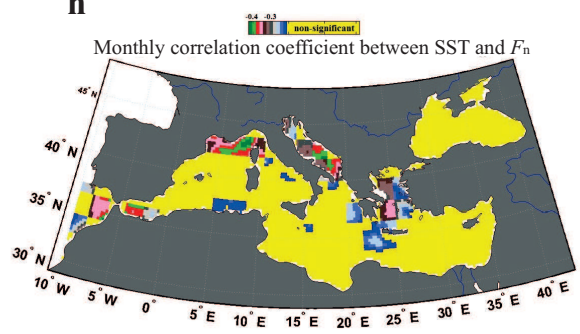

g

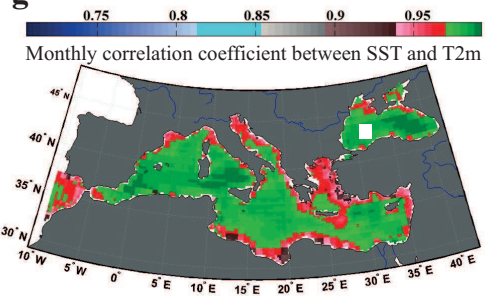

i

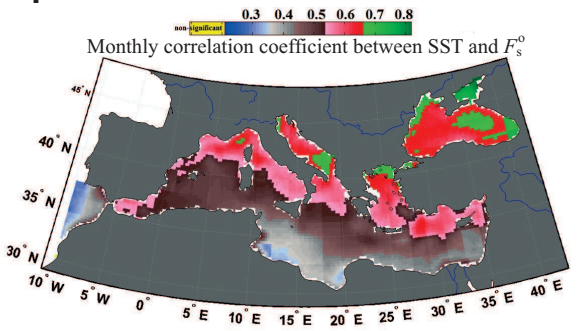

Figure 5. Monthly correlation coefficient between SST and the atmospheric components studied 
Table 1. Monthly coefficients of correlation between SST and the studied atmospheric components over the study area $(n=372$, level of significance $=95 \%$ ); the percentage of the study area significantly correlated with the studied atmospheric components is shown

\begin{tabular}{|c|c|c|c|c|}
\hline & \multicolumn{4}{|c|}{ Annual [\%] } \\
\hline & Winter & Spring & Summer & Autumn \\
\hline \multirow{2}{*}{$\begin{array}{l}\text { North Atlantic } \\
\text { Oscillation Index }\end{array}$} & \multicolumn{4}{|c|}{$85 \%$} \\
\hline & $12 \%$ & $13 \%$ & $6 \%$ & $22 \%$ \\
\hline \multirow{2}{*}{ Sea level pressure } & \multicolumn{4}{|c|}{$71 \%$} \\
\hline & $10 \%$ & $59 \%$ & $40 \%$ & $45 \%$ \\
\hline \multirow{2}{*}{ Precipitation } & \multicolumn{4}{|c|}{$72 \%$} \\
\hline & $12 \%$ & $83 \%$ & $15 \%$ & 22 \\
\hline \multirow{2}{*}{ Total cloud cover } & \multicolumn{4}{|c|}{$98 \%$} \\
\hline & $2[\%]$ & $99 \%$ & $41 \%$ & 86 \\
\hline \multirow{2}{*}{ Eastward wind stress } & \multicolumn{4}{|c|}{$46 \%$} \\
\hline & $1 \%$ & $48 \%$ & $22 \%$ & $59 \%$ \\
\hline \multirow{2}{*}{ Northward wind stress } & \multicolumn{4}{|c|}{$49 \%$} \\
\hline & $7 \%$ & $52 \%$ & $27 \%$ & $43 \%$ \\
\hline \multirow{2}{*}{$\begin{array}{l}\text { Air temperature } 2 \mathrm{~m} \\
\text { above sea level }\end{array}$} & \multicolumn{4}{|c|}{$100 \%$} \\
\hline & $89 \%$ & $100 \%$ & $100 \%$ & $100 \%$ \\
\hline \multirow{2}{*}{$\begin{array}{l}\text { Net heat loss } \\
\text { from the sea }\end{array}$} & \multicolumn{4}{|c|}{$20 \%$} \\
\hline & $14 \%$ & $28 \%$ & $28 \%$ & $59 \%$ \\
\hline \multirow{2}{*}{$\begin{array}{l}\text { Solar radiation to the } \\
\text { open water surface }\end{array}$} & \multicolumn{4}{|c|}{$99 \%$} \\
\hline & $48 \%$ & $99 \%$ & $45 \%$ & $100 \%$ \\
\hline
\end{tabular}

The effect of air-sea heat fluxes on SST displays seasonal behaviour. The percentage of the study area in which $F_{n}$ significantly affects SST ranges from $14 \%$ in winter to $59 \%$ in autumn. However, the percentage of the study area in which $F_{s}^{o}$ significantly affects SST ranges from $45 \%$ in summer to $100 \%$ in autumn. This result supports the previous findings of Skliris et al. (2012), who found that the Mediterranean SST variability is largely explained by air-sea heat fluxes.

Analysis of results for the different $F_{n}$ components indicates that the study area SST is explained by the sensible heat flux, net long-wave radiation and latent heat flux values. This is in disagreement with the 
previous findings of Skliris et al. (2012), who stated that the latent heat explains more of the Mediterranean SST than do the other $F_{n}$ components. This disagreement is probably because Skliris et al. (2012) examined a study period extending only from 1985 to 2008 and used a different database to extract air-sea heat fluxes.

Annual correlations between SST and NAO, SLP, P, TCC, $\tau_{a x}, \tau_{a y}, \mathrm{~T} 2 \mathrm{~m}$, $F_{n}$ and $F_{s}^{o}$ were significant over $38 \%, 55 \%, 16 \%, 55 \%, 18 \%, 25 \%, 100 \%, 54 \%$ and $26 \%$ of the study area respectively (data not shown). This may indicate that the interannual correlations of the studied atmospheric parameters explain less of the Mediterranean SST variability over the study area than do the monthly correlations. The only exception is $F_{n}$, the inter-annual correlations of which explain more of the Mediterranean SST variability than do the monthly correlation.

\subsection{Mediterranean sub-basin sea surface temperature characteristics}

In this section, time series analysis is used to reveal the SST variation between the 10 sub-basins of the study area, all of which display an annual positive trend ranging from $0.024^{\circ} \mathrm{C} \mathrm{yr}^{-1}$ to $0.05^{\circ}{\mathrm{C} \mathrm{yr}^{-1}}_{\text {(Figure } 6}$ and Table 2).

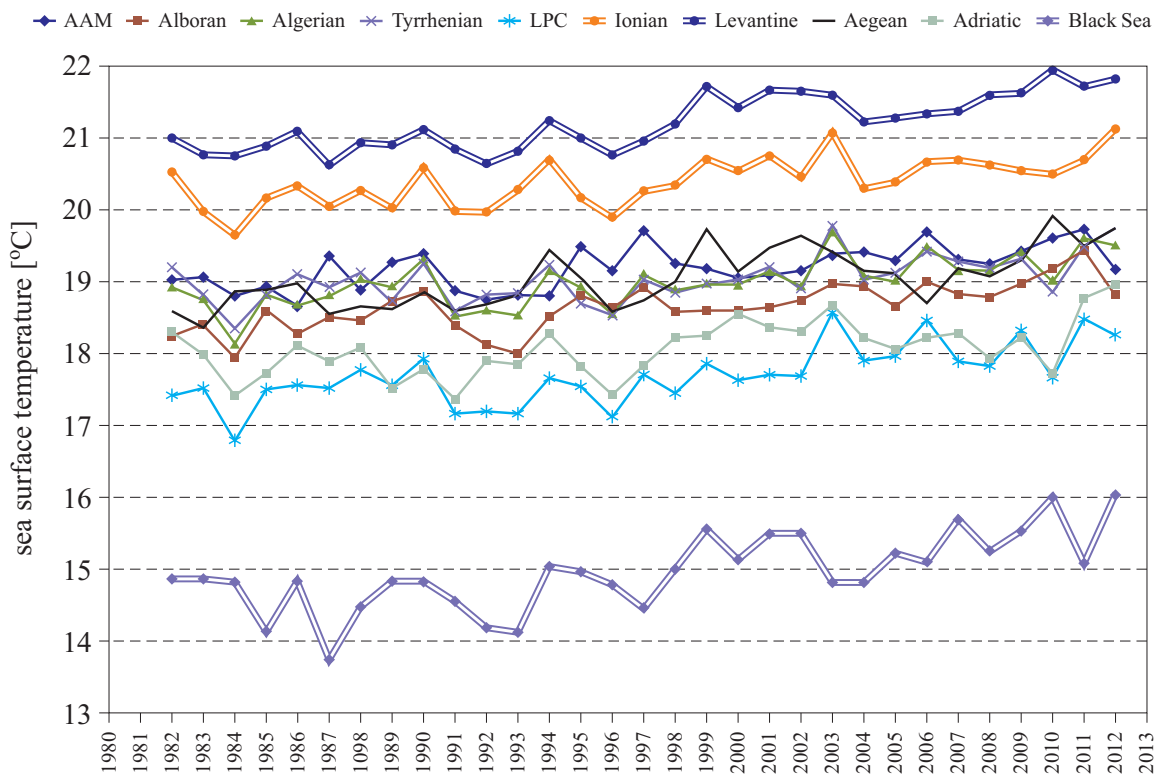

Figure 6. SST time series for the various sub-basins based on daily AVHRR data $(\mathrm{AAM}=$ Active Atlantic Mediterranean sub-basin to the west of the Strait of Gibraltar) 
Table 2. Annual and seasonal SST characteristics of the study area sub-basins based on daily data from 1982 to 2012 ; all linear trend analyses were tested for significance using the $t$-test at a $95 \%$ significance level

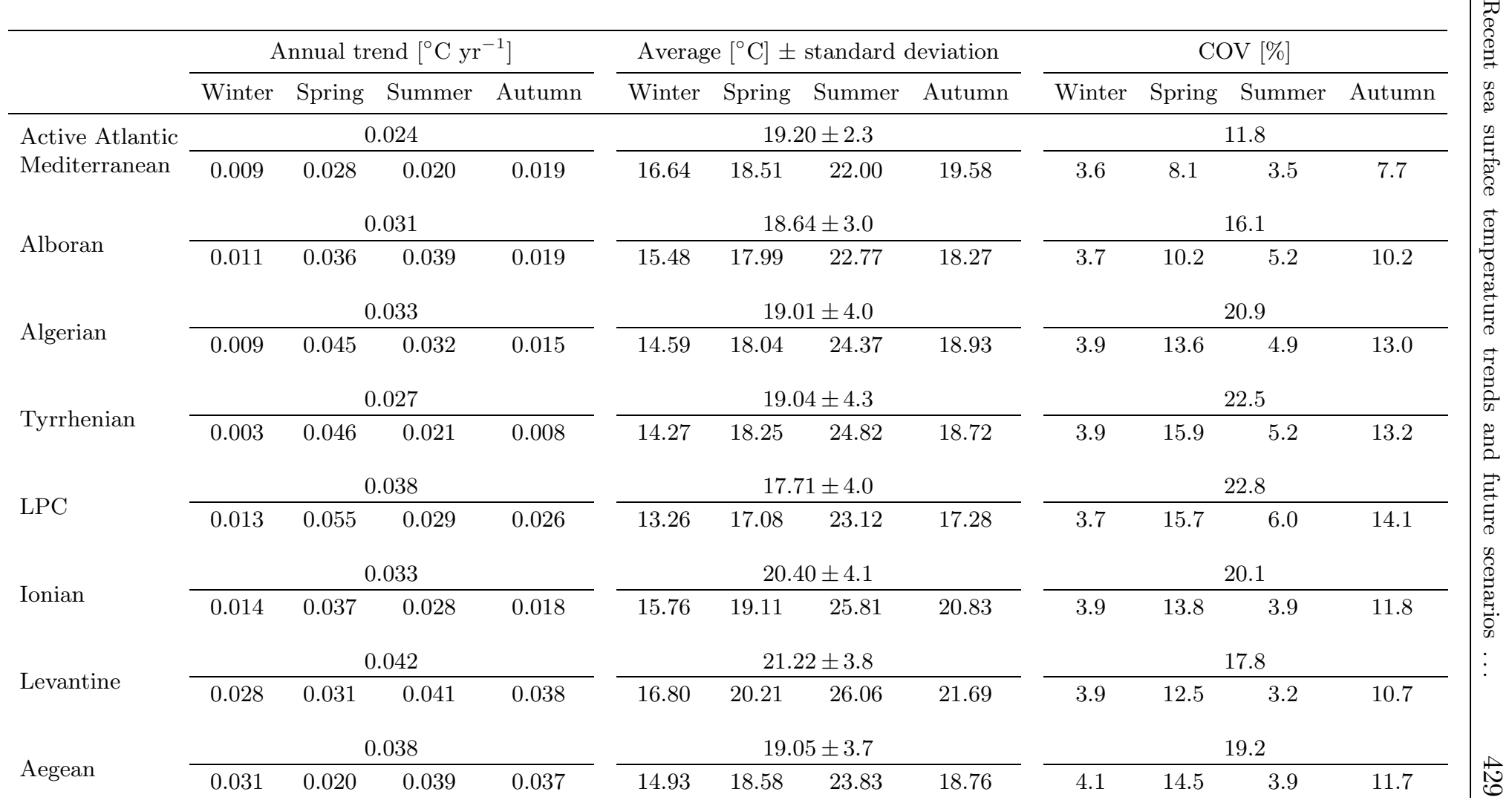


Table 2. (continued)

\begin{tabular}{|c|c|c|c|c|c|c|c|c|}
\hline & \multicolumn{4}{|c|}{ Minimum ${ }^{\circ} \mathrm{C}[\mathrm{yr}]$} & \multicolumn{4}{|c|}{ Maximum ${ }^{\circ} \mathrm{C}[\mathrm{yr}]$} \\
\hline & Winter & Spring & Summer & Autumn & Winter & Spring & Summer & Autumn \\
\hline $\begin{array}{l}\text { Active Atlantic } \\
\text { Mediterranean }\end{array}$ & $\begin{array}{l}16.03 \\
(2009)\end{array}$ & $\begin{array}{c}17.6 \\
(1986)\end{array}$ & $\begin{array}{l}21.4 \\
(2002)\end{array}$ & $\begin{array}{c}18.8 \\
(1993)\end{array}$ & $\begin{array}{c}17.44 \\
(1998)\end{array}$ & $\begin{array}{c}19.7 \\
(2011)\end{array}$ & $\begin{array}{c}23 \\
(2006)\end{array}$ & $\begin{array}{c}20.4 \\
(2006)\end{array}$ \\
\hline Alboran & $\begin{array}{c}14.8 \\
(2009)\end{array}$ & $\begin{array}{c}16.2 \\
(1984)\end{array}$ & $\begin{array}{c}21.7 \\
(1982)\end{array}$ & $\begin{array}{c}17.3 \\
(1992)\end{array}$ & $\begin{array}{c}16.1 \\
(1990)\end{array}$ & $\begin{array}{c}19 \\
(2011)\end{array}$ & $\begin{array}{c}23.8 \\
(2010)\end{array}$ & $\begin{array}{c}19.2 \\
(1983)\end{array}$ \\
\hline Algerian & $\begin{array}{c}14 \\
(1987)\end{array}$ & $\begin{array}{c}16.7 \\
(1984)\end{array}$ & $\begin{array}{c}23.1 \\
(1984)\end{array}$ & $\begin{array}{c}17.8 \\
(1996)\end{array}$ & $\begin{array}{c}15.7 \\
(1990)\end{array}$ & $\begin{array}{c}18.9 \\
(2003)\end{array}$ & $\begin{array}{c}25.9 \\
(2003)\end{array}$ & $\begin{array}{c}20 \\
(2011)\end{array}$ \\
\hline Tyrrhenian & $\begin{array}{c}13.6 \\
(1987)\end{array}$ & $\begin{array}{c}17 \\
(1984)\end{array}$ & $\begin{array}{c}23.8 \\
(1984)\end{array}$ & $\begin{array}{c}17.6 \\
(1996)\end{array}$ & $\begin{array}{c}15.1 \\
(1990)\end{array}$ & $\begin{array}{c}19.7 \\
(2003)\end{array}$ & $\begin{array}{c}26.2 \\
(2003)\end{array}$ & $\begin{array}{c}19.5 \\
(2006)\end{array}$ \\
\hline LPC & $\begin{array}{c}12.8 \\
(1987)\end{array}$ & $\begin{array}{c}15.7 \\
(1984)\end{array}$ & $\begin{array}{c}21.7 \\
(1984)\end{array}$ & $\begin{array}{c}16.1 \\
(1993)\end{array}$ & $\begin{array}{c}13.9 \\
(1990)\end{array}$ & $\begin{array}{c}18.3 \\
(2003)\end{array}$ & $\begin{array}{c}24.9 \\
(2003)\end{array}$ & $\begin{array}{l}18.8 \\
(2011)\end{array}$ \\
\hline Ionian & $\begin{array}{c}15.1 \\
(1987)\end{array}$ & $\begin{array}{c}18.1 \\
(1984)\end{array}$ & $\begin{array}{c}24.6 \\
(1984)\end{array}$ & $\begin{array}{c}20 \\
(1996)\end{array}$ & $\begin{array}{c}16.5 \\
(2007)\end{array}$ & $\begin{array}{c}20.1 \\
(2003)\end{array}$ & $\begin{array}{c}26.9 \\
(2003)\end{array}$ & $\begin{array}{c}22 \\
(2012)\end{array}$ \\
\hline
\end{tabular}


Table 2. (continued)

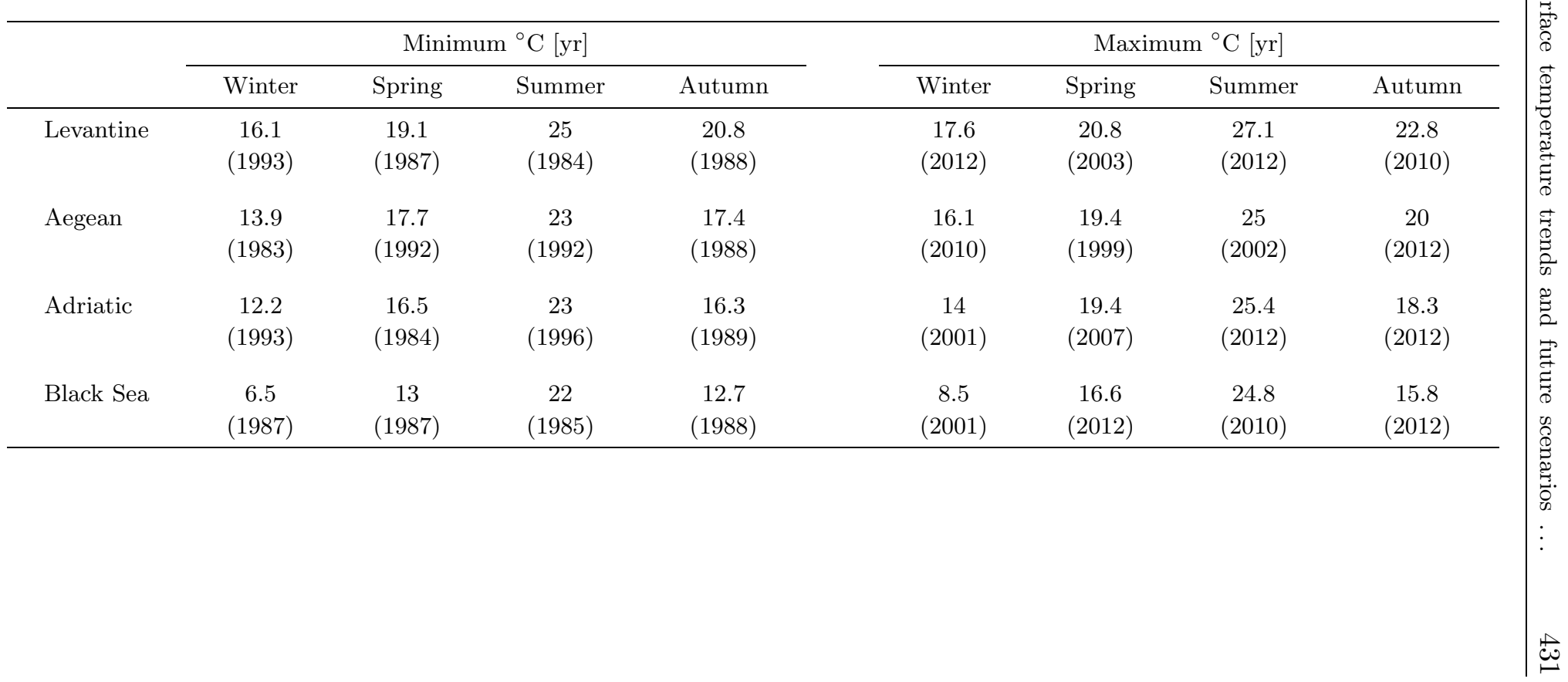


The 10 studied sub-basins display a range of annual average SST values of approximately $6.2^{\circ} \mathrm{C}$, ranging from $15.0^{\circ} \mathrm{C}$ in the Black Sea to $21.2^{\circ} \mathrm{C}$ in the Levantine sub-basin. The annual average SST of the AAM sub-basin is approximately $0.6^{\circ} \mathrm{C}$ higher than that of the adjacent Mediterranean Sea sub-basin, i.e. the Alboran sub-basin, most markedly in autumn. However, the annual average SST of the Black Sea is approximately $4.1^{\circ} \mathrm{C}$ lower than that of the adjacent Mediterranean Sea subbasin, i.e. the Aegean sub-basin, most markedly in winter (Figure 6 and Table 2).

The annual average COV of the study area SST displays important spatial variability: the maximum variability occurs over the Black Sea $(\mathrm{COV}=42 \%)$, while the minimum variability occurs over the AAM sub-basin $(\mathrm{COV}=11.8 \%)$. In addition, the COV of the study area SST displays important seasonal variability, ranging from maximum values in spring to minimum values in summer (Table 2).

Generally, an annual time series for the Aegean SST is used to explain the Eastern Mediterranean Transient (EMT) phenomenon. Much colder winters (winter mean temperature minus winter standard deviation $<14.5^{\circ} \mathrm{C}$ ) occurred in 1983, 1996, 1989, 2006 and 1993 (the years are ordered according to winter temperature starting from the lowest one), whereas much warmer winters (winter mean temperature plus winter standard deviation $>15.4^{\circ} \mathrm{C}$ ) occurred in 2005, 2011 and 2010 (the years are ordered according to winter temperature starting from the highest one) (data not shown). The cold winter in 1993 may explain the initiation of the EMT over the southern Aegean Sea in the early 1990s. The EMT (Klein et al. 1999) formed because the Aegean Sea salinity increased from 1987 to 1991, followed by cold winters in 1992 and 1993.

\subsection{Scenarios}

In this section, the SSTs up to 2100 projected using the RCP26, RCP45, RCP60 and RCP80 scenarios are investigated using CMIP5 ensemble means.

\subsubsection{Control period examined: $1982-2012$}

Table 3 shows the performance of various CMIP5 ensemble mean scenarios used to estimate SST values. The SSTs obtained are compared directly with AVHRR SST annual and monthly data. The results in Table 3 are subjected to the $t$-test to determine whether the SSTs obtained using 
Table 3. Differences in CMIP5 ensemble mean SST according to different scenario runs (i.e. RCP26, RCP45, RCP60 and RCP85) relative to AVHRR-derived SST (present study) for the 1982-2012 control period; ensemble mean based on 24 global climate models (Med $=$ Mediterranean Sea, AAM = Active Atlantic Mediterranean)

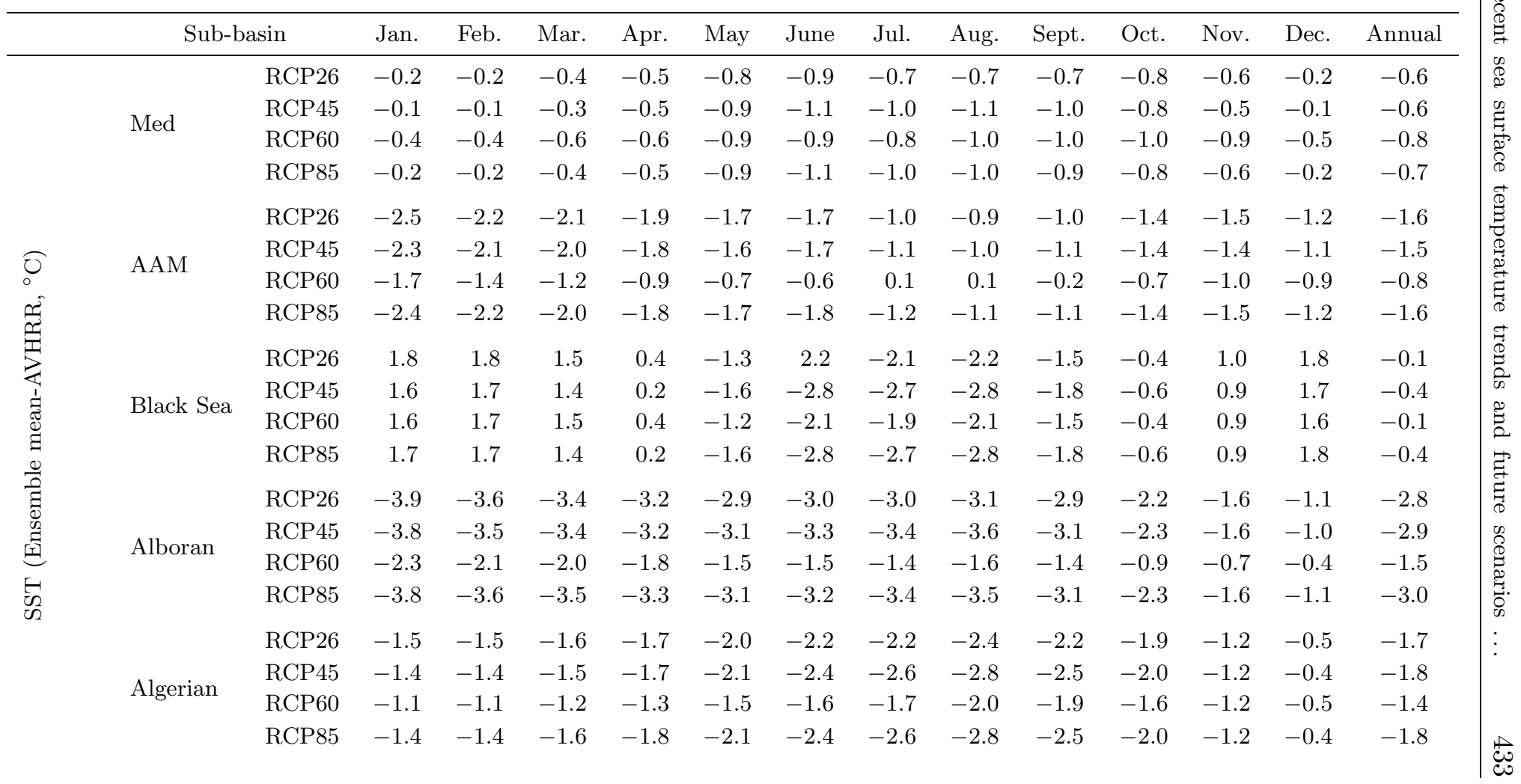


Table 3. (continued)

\begin{tabular}{|c|c|c|c|c|c|c|c|c|c|c|c|c|c|c|c|}
\hline & Sub-b & & Jan. & Feb. & Mar. & Apr. & May & June & Jul. & Aug. & Sept. & Oct. & Nov. & Dec. & Annual \\
\hline \multirow{24}{*}{ 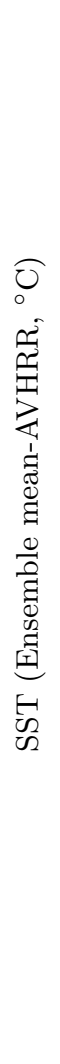 } & \multirow{4}{*}{ Tyrrhenian } & RCP26 & -1.0 & -1.0 & -1.2 & -1.4 & -2.1 & -2.3 & -2.3 & -2.3 & -1.8 & -1.6 & -1.2 & -0.4 & -1.6 \\
\hline & & $\mathrm{RCP} 45$ & -0.9 & -0.9 & -1.1 & -1.3 & -2.1 & -2.4 & -2.6 & -2.6 & -1.9 & -1.6 & -1.1 & -0.4 & -1.6 \\
\hline & & RCP60 & -0.6 & -0.6 & -0.8 & -1.0 & -1.7 & -1.7 & -1.8 & -1.9 & -1.5 & -1.3 & -1.0 & -0.3 & -1.2 \\
\hline & & $\mathrm{RCP} 85$ & -1.0 & -0.9 & -1.2 & -1.4 & -2.1 & -2.4 & -2.5 & -2.5 & -1.9 & -1.6 & -1.1 & -0.4 & -1.6 \\
\hline & \multirow{4}{*}{ LPC } & RCP26 & -1.1 & -1.1 & -1.3 & -1.3 & -1.9 & -2.0 & -1.8 & -1.8 & -1.3 & -1.1 & -0.6 & 0.0 & -1.3 \\
\hline & & $\mathrm{RCP} 45$ & -0.9 & -1.0 & -1.2 & -1.3 & -1.8 & -2.1 & -2.1 & -2.1 & -1.4 & -1.0 & -0.5 & 0.1 & -1.3 \\
\hline & & RCP60 & -0.7 & -0.7 & -0.9 & -1.0 & -1.5 & -1.4 & -1.2 & -1.3 & -1.0 & -1.0 & -0.6 & -0.1 & -1.0 \\
\hline & & $\mathrm{RCP} 85$ & -1.0 & -1.1 & -1.2 & -1.3 & -1.9 & -2.1 & -2.1 & -2.0 & -1.4 & -1.0 & -0.5 & 0.1 & -1.3 \\
\hline & \multirow{4}{*}{ Ionian } & RCP26 & -0.6 & -0.4 & -0.5 & -0.7 & -1.0 & -1.3 & -1.3 & -1.4 & -1.5 & -1.5 & -1.2 & -0.6 & -1.0 \\
\hline & & $\mathrm{RCP} 45$ & -0.5 & -0.4 & -0.5 & -0.6 & -1.0 & -1.4 & -1.6 & -1.7 & -1.6 & -1.5 & -1.2 & -0.5 & -1.0 \\
\hline & & RCP60 & -0.4 & -0.3 & -0.4 & -0.4 & -0.7 & -1.0 & -1.2 & -1.4 & -1.4 & -1.4 & -1.2 & -0.5 & -0.9 \\
\hline & & RCP 85 & -0.6 & -0.5 & -0.6 & -0.7 & -1.1 & -1.4 & -1.5 & -1.6 & -1.6 & -1.5 & -1.2 & -0.6 & -1.1 \\
\hline & \multirow{4}{*}{ Levantine } & RCP26 & -1.0 & -0.9 & -1.0 & -1.0 & -1.3 & -1.4 & -1.2 & -1.2 & -1.4 & -1.5 & -1.2 & -0.9 & -1.2 \\
\hline & & RCP 45 & -1.0 & -0.9 & -0.9 & -1.1 & -1.4 & -1.7 & -1.6 & -1.6 & -1.7 & -1.6 & -1.2 & -0.9 & -1.3 \\
\hline & & $\mathrm{RCP} 60$ & -0.9 & -0.7 & -0.8 & -0.9 & -1.2 & -1.4 & -1.2 & -1.2 & -1.4 & -1.4 & -1.2 & -0.9 & -1.1 \\
\hline & & $\mathrm{RCP} 85$ & -1.1 & -1.0 & -1.0 & -1.1 & -1.4 & -1.7 & -1.6 & -1.6 & -1.7 & -1.6 & -1.2 & -0.9 & -1.3 \\
\hline & \multirow{4}{*}{ Aegean } & RCP26 & -1.7 & -1.8 & -1.7 & -1.7 & -1.9 & -2.0 & -1.6 & -1.7 & -1.8 & -1.5 & -0.9 & -0.6 & -1.6 \\
\hline & & $\mathrm{RCP} 45$ & -1.8 & -1.8 & -1.8 & -1.8 & -2.0 & -2.3 & -1.9 & -2.1 & -2.1 & -1.6 & -1.0 & -0.7 & -1.7 \\
\hline & & RCP60 & -1.8 & -1.9 & -1.9 & -1.7 & -1.6 & -1.5 & -0.8 & -1.0 & -1.3 & -1.1 & -0.9 & -1.0 & -1.4 \\
\hline & & $\mathrm{RCP} 85$ & -1.7 & -1.8 & -1.7 & -1.8 & -2.0 & -2.2 & -1.8 & -2.0 & -2.0 & -1.5 & -0.9 & -0.6 & -1.7 \\
\hline & \multirow{4}{*}{ Adriatic } & RCP26 & -2.5 & -2.4 & -2.6 & -3.0 & -4.2 & -4.7 & -4.6 & -4.5 & -3.4 & -2.4 & -1.3 & -0.6 & -3.0 \\
\hline & & $\mathrm{RCP} 45$ & -2.4 & -2.2 & -2.5 & -2.9 & -4.2 & -4.9 & -5.0 & -4.8 & -3.5 & -2.4 & -1.3 & -0.5 & -3.0 \\
\hline & & RCP60 & -1.2 & -1.2 & -1.5 & -1.9 & -2.8 & -2.8 & -2.5 & -2.5 & -1.8 & -1.2 & -0.7 & -0.5 & -1.7 \\
\hline & & RCP85 & -2.5 & -2.4 & -2.6 & -3.1 & -4.2 & -4.8 & -4.8 & -4.6 & -3.5 & -2.5 & -1.4 & -0.6 & -3.1 \\
\hline
\end{tabular}


CMIP5 ensemble means are significantly lower or higher than the AVHRR SST values.

The annual CMIP5 ensemble mean scenarios significantly underestimate SST over the study area, most markedly over the Adriatic sub-basin $\left(\approx 3.1^{\circ} \mathrm{C}\right)$ and in June.

The Mediterranean Sea and the AAM sub-basin display significant monthly variation in the lower SST estimates, especially in January. In contrast, the Black Sea displays higher monthly SST estimates in cold months and lower monthly SST estimates in hot months.

Generally, CMIP5 ensemble mean scenarios result in estimated SSTs that are much lower than those observed from AVHRR satellite images during the examined control period, indicating that the study area SST may be much higher than that projected for the end of the current century using CMIP5 ensemble means.

\subsubsection{Future climate change: $2000-2100$}

All CMIP5 ensemble means used for SST scenarios indicate a significant warming over the 2000-2100 period in the study area, most (least) markedly using the RCP85 (RCP26) scenario, as seen in Figure 7a and Table 4, i.e. in the AAM sub-basin $\left(0.3-1.6^{\circ} \mathrm{C}\right)$, Mediterranean Sea $\left(0.5-2.6^{\circ} \mathrm{C}\right)$ and Black Sea $\left(0.5-2.6^{\circ} \mathrm{C}\right)$.

The AAM sub-basin displays the weakest warming trend in the current century, weaker than those of the Black and Mediterranean Seas. The Mediterranean Sea displays spatial variability in warming trends between its various sub-basins, the maximum (minimum) warming trend occurring in the Ionian and Levantine sub-basins (Alboran sub-basin), as seen in Table 4.

All eight Mediterranean Sea sub-basins are projected to warm significantly, most (least) pronounced over the Levantine (Alboran) sub-basin. The Levantine (Alboran) sub-basin is projected to warm during the 21st century by amounts ranging from $0.44^{\circ} \mathrm{C}\left(0.29^{\circ} \mathrm{C}\right)$ using the RCP26 scenario to $2.53^{\circ} \mathrm{C}\left(1.63^{\circ} \mathrm{C}\right)$ using the $\mathrm{RCP} 85$ scenario (data not shown).

In general, there is significant variability in seasonal warming, expressed as SST, during the current century for the different CMIP5 ensemble mean scenarios. The Mediterranean Sea SST is projected to warm significantly in each scenario, especially in summer $\left(2.92-0.47^{\circ} \mathrm{C}\right.$ century $\left.{ }^{-1}\right)$, as seen in Figure 7b. Similarly, the AAM sub-basin is projected to warm significantly, ranging from a maximum of $1.68-0.31^{\circ} \mathrm{C}$ century ${ }^{-1}$ in summer to a minimum of $1.35-0.29^{\circ} \mathrm{C}_{\text {century }}{ }^{-1}$ in winter. Moreover, the Black Sea 

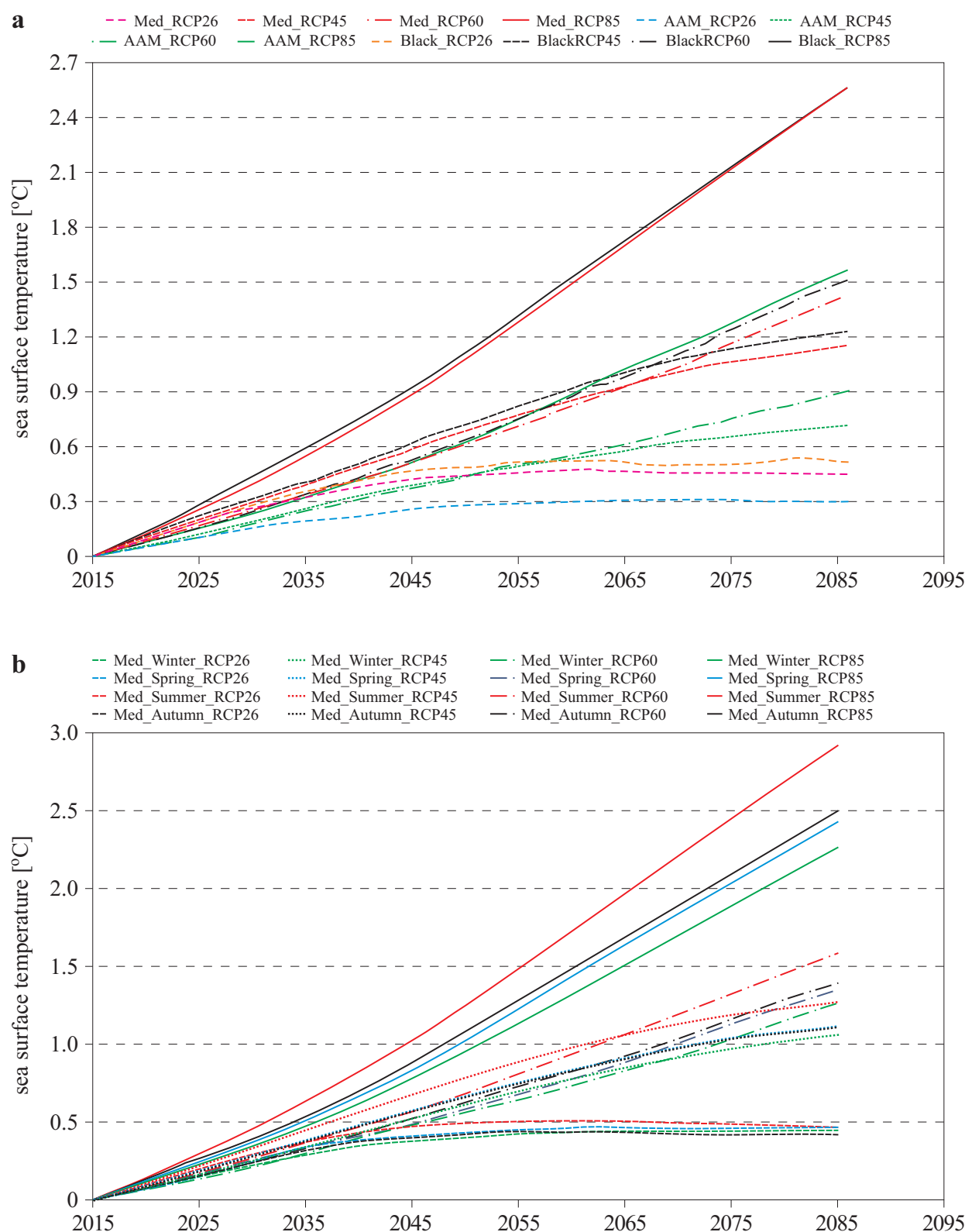

Figure 7. Thirty-year running (a) annual and (b) seasonal SST means with reference to the 2000-2029 period for the various RCP scenarios

is also projected to warm significantly, ranging from a maximum of 2.81$0.53^{\circ} \mathrm{C}$ century $^{-1}$ in summer to a minimum of $2.33-0.51^{\circ} \mathrm{C}_{\text {century }}{ }^{-1}$ in winter (data not shown). 
Table 4. Change in CMIP5 ensemble mean SST in the various sub-basins at the end of the 21st century (relative to SST, 2000-2029) for the various RCP scenarios

\begin{tabular}{|c|c|c|c|c|c|c|}
\hline \multicolumn{2}{|c|}{ Sub-basin } & \multirow{2}{*}{$\begin{array}{c}\text { Winter } \\
0.4\end{array}$} & \multirow{2}{*}{$\begin{array}{c}\text { Spring } \\
0.5\end{array}$} & \multirow{2}{*}{$\begin{array}{c}\text { Summer } \\
0.5\end{array}$} & \multirow{2}{*}{$\begin{array}{c}\text { Autumn } \\
0.4\end{array}$} & \multirow{2}{*}{$\begin{array}{c}\text { Annual } \\
0.5\end{array}$} \\
\hline \multirow{4}{*}{ Med } & RCP26 & & & & & \\
\hline & $\mathrm{RCP} 45$ & 1.1 & 1.1 & 1.3 & 1.1 & 1.2 \\
\hline & RCP60 & 1.3 & 1.4 & 1.6 & 1.4 & 1.4 \\
\hline & RCP85 & 2.3 & 2.4 & 2.9 & 2.5 & 2.6 \\
\hline \multirow{4}{*}{ AAM } & RCP26 & 0.3 & 0.3 & 0.3 & 0.3 & 0.3 \\
\hline & RCP45 & 0.6 & 0.7 & 0.8 & 0.7 & 0.7 \\
\hline & RCP60 & 0.8 & 0.9 & 1.0 & 0.9 & 0.9 \\
\hline & $\mathrm{RCP} 85$ & 1.3 & 1.5 & 1.7 & 1.6 & 1.6 \\
\hline \multirow{4}{*}{ Black Sea } & RCP26 & 0.5 & 0.6 & 0.5 & 0.5 & 0.5 \\
\hline & RCP45 & 1.1 & 1.3 & 1.3 & 1.2 & 1.2 \\
\hline & RCP60 & 1.3 & 1.5 & 1.6 & 1.4 & 1.5 \\
\hline & $\mathrm{RCP} 85$ & 2.3 & 2.6 & 2.8 & 2.4 & 2.6 \\
\hline \multirow{4}{*}{ Alboran } & $\mathrm{RCP} 26$ & 0.3 & 0.3 & 0.3 & 0.3 & 0.3 \\
\hline & RCP45 & 0.6 & 0.7 & 0.8 & 0.7 & 0.7 \\
\hline & RCP60 & 0.7 & 0.9 & 1.2 & 0.9 & 0.9 \\
\hline & RCP85 & 1.2 & 1.6 & 2.0 & 1.6 & 1.6 \\
\hline \multirow{4}{*}{ Algerian } & RCP26 & 0.4 & 0.4 & 0.5 & 0.4 & 0.4 \\
\hline & RCP45 & 0.9 & 0.9 & 1.2 & 1.0 & 1.0 \\
\hline & RCP60 & 1.0 & 1.2 & 1.5 & 1.2 & 1.2 \\
\hline & RCP85 & 1.8 & 2.0 & 2.6 & 2.2 & 2.2 \\
\hline \multirow{4}{*}{ Tyrrhenian } & RCP26 & 0.4 & 0.4 & 0.4 & 0.4 & 0.4 \\
\hline & RCP45 & 1.0 & 1.0 & 1.2 & 1.0 & 1.1 \\
\hline & RCP60 & 1.1 & 1.2 & 1.5 & 1.3 & 1.3 \\
\hline & RCP85 & 2.1 & 2.2 & 2.9 & 2.4 & 2.4 \\
\hline \multirow{4}{*}{ LPC } & RCP26 & 0.4 & 0.4 & 0.4 & 0.4 & 0.4 \\
\hline & $\mathrm{RCP} 45$ & 0.9 & 1.0 & 1.2 & 1.0 & 1.0 \\
\hline & RCP60 & 1.1 & 1.2 & 1.6 & 1.3 & 1.3 \\
\hline & $\mathrm{RCP} 85$ & 1.9 & 2.1 & 2.7 & 2.3 & 2.3 \\
\hline \multirow{4}{*}{ Ionian } & $\mathrm{RCP} 26$ & 0.4 & 0.5 & 0.5 & 0.4 & 0.4 \\
\hline & $\mathrm{RCP} 45$ & 1.1 & 1.1 & 1.2 & 1.1 & 1.1 \\
\hline & RCP60 & 1.3 & 1.3 & 1.6 & 1.4 & 1.4 \\
\hline & $\mathrm{RCP} 85$ & 2.3 & 2.4 & 2.9 & 2.5 & 2.5 \\
\hline \multirow{4}{*}{ Levantine } & RCP26 & 0.5 & 0.5 & 0.4 & 0.4 & 0.4 \\
\hline & RCP45 & 1.1 & 1.1 & 1.2 & 1.1 & 1.1 \\
\hline & RCP60 & 1.3 & 1.4 & 1.5 & 1.4 & 1.4 \\
\hline & RCP85 & 2.3 & 2.5 & 2.8 & 2.5 & 2.5 \\
\hline
\end{tabular}


Table 4. (continued)

\begin{tabular}{ccccccc}
\hline \multicolumn{2}{c}{ Sub-basin } & Winter & Spring & Summer & Autumn & Annual \\
\hline \multirow{6}{*}{ Aegean } & RCP26 & 0.4 & 0.4 & 0.4 & 0.4 & 0.4 \\
& RCP45 & 1.0 & 1.1 & 1.1 & 1.0 & 1.1 \\
& RCP60 & 1.4 & 1.4 & 1.5 & 1.4 & 1.4 \\
& RCP85 & 2.2 & 2.4 & 2.5 & 2.2 & 2.4 \\
& RCP26 & 0.4 & 0.4 & 0.4 & 0.4 & 0.4 \\
& RCP45 & 1.0 & 1.0 & 1.1 & 1.0 & 1.0 \\
& RCP60 & 1.4 & 1.3 & 1.5 & 1.5 & 1.4 \\
& RCP85 & 2.0 & 2.0 & 2.5 & 2.1 & 2.2 \\
\hline
\end{tabular}

\section{Conclusion}

Mediterranean Sea surface variability is affected by a combination of oceanic and atmospheric processes and displays significant regional and seasonal behaviour. AVHRR gridded annual SST data over the Mediterranean Sea indicate a range of $3.5^{\circ} \mathrm{C}$ between a maximum SST of $21.2^{\circ} \mathrm{C}$ over the Levantine sub-basin and a minimum SST of $17.7^{\circ} \mathrm{C}$ over the LPC sub-basin. These data also indicate a seasonal SST range of $10^{\circ} \mathrm{C}$, ranging from $15.2^{\circ} \mathrm{C}$ in winter, through $18.8^{\circ} \mathrm{C}$ in spring and $19.8^{\circ} \mathrm{C}$ in autumn, to $25^{\circ} \mathrm{C}$ in summer.

The Mediterranean SST is significantly warming by $0.35^{\circ} \mathrm{C}$ decade ${ }^{-1}$, with a seasonal trend variability peaking in spring at $0.38^{\circ} \mathrm{C}$ decade $^{-1}$ followed by $0.32^{\circ} \mathrm{C}$ decade $^{-1}$ in summer, $0.22^{\circ} \mathrm{C}$ decade $^{-1}$ in autumn and $0.160^{\circ} \mathrm{C}$ decade $^{-1}$ in winter. However, the Black Sea (AAM sub-basin) displays a higher (lower) warming trend of $0.51^{\circ} \mathrm{C}$ decade $^{-1}\left(0.24^{\circ} \mathrm{C}\right.$ decade $\left.^{-1}\right)$. This annual Mediterranean warming trend agrees with the previous findings of Nykjaer (2009) and Skliris et al. (2012) but runs counter to those of D'Ortenzio et al. (2000). The disagreement with D'Ortenzio et al. (2000) is probably due to the examination of different time periods. However, the annual Black Sea SST warming trend found here is less significant than the trends calculated by Belkin (2009), probably because Belkin's study period extends only to 2002 .

The spatial distribution of SST warming trends leads to significant eddies distributed over the Mediterranean Sea, indicating significant changes in the Mediterranean Sea surface circulation in the near future.

The SST warming trends in the various Mediterranean sub-basins are more (less) significant than the SST warming trends in the AAM subbasin (Black Sea). Similarly, the COV values for the SSTs of the various Mediterranean sub-basins are higher (lower) than those for the AAM subbasin (Black Sea). 
At the $95 \%$ significance level, the monthly Mediterranean SST is significantly affected by atmospheric temperature $(R=98 \%)$, total cloud cover $(R=-0.81)$, solar radiation to the open water surface $(R=72 \%)$, net heat loss from the sea $(R=-53 \%)$, precipitation $(R=-0.53)$, SLP $(R=-0.43)$, eastward wind stress $(R=-0.33)$ and northward wind stress $(R=-33 \%)$, and NAOI $(R=-0.27)$. The low significant correlation between NAOI and the Mediterranean SST agrees with the previous findings of Skliris et al. (2012). However, the high significant correlation between the Mediterranean SST and total cloud cover agrees with the previous findings of Brierley \& Fedorov (2010). In addition, the Mediterranean SST warming trend follows the negative trend of heat loss through the open water surface; this is also in agreement with the findings of Skliris et al. (2012).

In the last part of the paper, future SST uncertainty over the study period is described using CMIP5 ensemble mean scenarios (i.e. RCP26, RCP45, RCP60 and RCP85). Based on direct comparison between AVHRR SST data and the results of various CMIP5 ensemble mean scenario control runs for the examined period (i.e. 2000-2012), the RCP26 scenario control run is found to be closest to the AVHRR SST data, displaying annual estimates that are $0.5,1.6$ and $0.2^{\circ} \mathrm{C}$ lower for the Mediterranean Sea, AAM sub-basin and Black Sea respectively.

In the 21st century, the generally expected warming of the annual Mediterranean SST ranges from $0.45^{\circ} \mathrm{C}$ in the RCP26 scenario, through $1.15^{\circ} \mathrm{C}$ in the $\mathrm{RCP} 45$ scenario and $1.42^{\circ} \mathrm{C}$ in the RCP60 scenario, to $2.56^{\circ} \mathrm{C}$ in the RCP85 scenario. In each scenario, the summer displayed the maximum warning trend. Moreover, the winter warming trend in the RCP85 scenario is higher than any other seasonal warming trends in the other three scenarios. The warming trends predicted using the RCP26, RCP45 and RCP60 scenarios are significantly lower than that predicted by Parry et al. (2007) using the B1 scenario. However, the significant warming predicted using the RCP85 scenario agrees with the Mediterranean SST warming that Parry et al. (2007) predicted using the A2 scenario.

Generally, the SST projected for the end of the current century is controlled mainly by emission variations rather than seasonal or regional variations, indicating that management efforts should emphasise emission reduction.

\section{Acknowledgements}

This research was undertaken when Dr Mohamed Shaltout was a visiting scientist at the Ocean Climate Group, Department of Earth Sciences, University of Gothenburg, Sweden. The work is a contribution to the Baltic Earth and HyMex programmes. We would like to thank Stephen Sanborn 
at Proper English AB for the English language editing. Financial support was gratefully received from the University of Gothenburg and the Swedish Research Council (contract No. 621-2007-3750).

\section{References}

Anonymous, 1988, Naval environmental prediction research facility, Tech. Rep. (U.S), Univ. California, $67 \mathrm{pp}$.

Bakun A., Agostini A., 2001, Seasonal pattern of wind induced upwelling/downwelling in the Mediterranean Sea, Sci. Mar., 65 (3), 243-257.

Belkin M., 2009, Rapid warming of large marine ecosystems, Prog. Oceanogr., 81 (1-4), 207-213, http://dx.doi.org/10.1016/j.pocean.2009.04.011.

Berrisford P., Dee D., Poli P., Brugge R., Fielding K., Fuentes M., Kallberg P., Kobayashi S., Uppala S., Simmons A., 2011, The ERA-Interim archive, version 2.0., ERA Rep. Ser. No. 1 (Tech. Rep.), European Centre for MediumRange Weather Forecasting (ECMWF), Reading, 23 pp.

Borzelli G., Manzella G., Marullo S., Santoleri R., 1999, Observations of coastal filaments in the Adriatic Sea, J. Marine Syst., 20 (1-4), 187-203, http://dx. doi.org/10.1016/S0924-7963(98)00082-7.

Brierley M., Fedorov V., 2010, Relative importance of meridional and zonal sea surface temperature gradients for the onset of the ice ages and PliocenePleistocene climate evolution, Paleoceanography, 25(2), PA2214, http://dx. doi.org/10.1029/2009PA001809.

Clarke L., Edmonds J., Jacoby H., Pitcher H., Reilly J., Richels R., 2007, Scenarios of greenhouse gas emissions and atmospheric concentrations. Sub-report 2.1a of Synthesis and Assessment Product 2.1., Climate Change Science Program and the Subcommittee on Global Change Research, Washington, DC.

Delgado J., Garcia-Lafuente J., Vargas M. J., 2001, A simple model for submaximal exchange through the Strait of Gibraltar, Sci. Mar., 65 (4), 313-322.

D'Ortenzio F., Marullo S., Santoleri R., 2000, Validation of AVHRR Pathfinder SSTs over the Mediterranean Sea, Geophys. Res. Lett., $27(2)$, 241-244, http://dx.doi.org/10.1029/1999GL002357.

Ginzburg A., Kostianoy A., Sheremet N., 2004, Seasonal and interannual variability of the Black Sea surface temperature as revealed from satellite data (19822000), J. Marine Syst., 52 (1-4), 33-50, http://dx.doi.org/10.1016/j.jmarsys. 2004.05.002.

Ferrarese S., Cassardo C., Elmi A., Genovese R., Longhetto A., Manfrin M., Richiardone R., 2009, Air-sea interactions in the Adriatic basin: simulations of Bora and Sirocco wind events, Geofizika, 26 (2), 157-170.

Fujino J., Nair R., Kainuma M., Masui T., Matsuoka Y., 2006, Multigas mitigation analysis on stabilization scenarios using aim global model, Energ. J., 3 (SI), 343-354. 
Jiang Q., Ronald B., Doyle J., 2003, The nature of the mistral: Observations and modelling of two MAP events, Q. J. Roy. Meteor. Soc., 129 (588), 857-875, http://dx.doi.org/10.1256/qj.02.21.

Jung T., Ferranti L., Tompkins M., 2006, Response to the summer of 2003 Mediterranean SST anomalies over Europe and Africa, J. Climate, 19 (20), 5439-5454, http://dx.doi.org/10.1175/JCLI3916.1.

IPCC, 2007, Climate change 2007: synthesis report. Contribution of working groups I-III to the Fourth assessment report of the Intergovernmental panel on climate change, Cambridge Univ. Press, Cambridge.

Klein B., Roether W., Manca B., Bregant D., Beitze V., Kovacevic V., Luchetta A., 1999, The large deep water transient in the Eastern Mediterranean, Deep-Sea Res. Pt. I, 46 (3), 371-414, http://dx.doi.org/10.1016/S0967-0637(98)00075-2.

Kotroni V., Lagouvardos K., Lalas D., 2001, The effect of the island of Crete on the Etesian winds over the Aegean Sea, Q. J. Roy. Meteor. Soc., $127(576)$, 1917-1937, http://dx.doi.org/10.1002/qj.49712757604.

Large W., Pond S., 1981, Open ocean momentum flux measurements in moderate to strong winds, J. Phys. Oceanogr., 11 (3), 324-336, http://dx.doi.org/10.1175/ 1520-0485(1981)011<0324:OOMFMI>2.0.CO;2.

Lelieveld J., Berresheim H., Borrmann S., Crutzen P., Dentener J., Fischer H., Feichter J., Flatau P. J., Heland J., Holzinger R., Korrmann R., Lawrence M. G., Levin Z., Markowicz K. M., Mihalopoulos N., Minikin A., Ramanathan V., De Reus M., Roelofs G.J., Scheeren H.A., Sciare J., Schlager H., Schultz M., Siegmund P., Steil B., Stephanou E. G., Stier P., Traub M., Warneke C., Williams J., Ziereis H., 2002, Global air pollution crossroads over the Mediterranean, Science, 298, 794-799, http://dx.doi.org/10.1126/science. 1075457.

Leitz M., 1999, Ionian sea surface temperature: satellite and drifter observations, May to October 1995, M. Sc. thesis, Naval Postgrad. School, Monterey, 106 pp.

Lionello P., Gacic M., Gomis D., Garcia-Herrera R., Giorgi F., Planton S., Trigo R., Theocharis A., Tsimplis M., Ulbrich U., Xoplaki E., 2010, Program focuses on climate of the Mediterranean region, EOS T. Am. Geophys. Un., 93 (10), 105-106, http://dx.doi.org/10.1029/2012EO100001.

Luterbacher J., Dietrich D., Xoplaki E., Grosjean M., Wanner H., 2004, European seasonal and annual temperature variability, trends, and extremes since 1500, Science, 303 (5663), 1499-1503, http://dx.doi.org/10.1126/science.1093877.

Marullo S., Buongiorno Nardelli B., Guarracino M., Santoleri R., 2007, Observing the Mediterranean Sea from space: 21 years of Pathfinder-AVHRR Sea Surface Temperatures (1985 to 2005). Re-analysis and validation, Ocean Sci., 3, 299310, http://dx.doi.org/10.5194/os-3-299-2007.

Marullo S., Santoleri R., Malanotte-Rizzoli P., Bergamasco A., 1999, The sea surface temperature field in the Eastern Mediterranean from advanced very high resolution radiometer (AVHRR) data: Part II. Interannual variability, J. Marine Syst., 20 (1-4), 83-112, http://dx.doi.org/10.1016/S0924-7963(98) 00072-4. 
Metaxas A., Bartzokas A., 1994, Pressure covariability over the Atlantic, Europe and N. Africa. Application: Centers of action for temperature, winter precipitation and summer winds in Athens, Greece, Theor. Appl. Climatol., 49 (1), 9-18, http://dx.doi.org/10.1007/BF00866284.

Millot C., 2005, Circulation in the Mediterranean Sea: evidences, debates and unanswered questions, Sci. Mar., 69 (S1), 5-21.

Nykjaer L., 2009, Mediterranean Sea surface warming 1985-2006, Climate Res., 39, 11-17, http://dx.doi.org/10.3354/cr00794.

Omstedt A., 2011, Guide to process based modeling of lakes and coastal seas, Springer-Verlag, Berlin, Heidelberg, 258 pp., http://dx.doi.org/10.1007/ 978-3-642-17728-6.

Parada M., Canton M., 1998, Sea surface temperature variability in Alboran sea from satellite data, Int. J. Remote Sens., 19 (13), 2439-2450, http://dx.doi. org/10.1080/014311698214541.

Parry M., Canziani O., Palutikof J., Linden P., Hanson C., 2007, Contribution of Working Group II to the Fourth Assessment Report of the Intergovernmental Panel on Climate Change, Cambridge Univ. Press, Cambridge, New York.

Poulain P., Menna M., Mauri E., 2012, Surface geostrophic circulation of the Mediterranean Sea derived from drifter and satellite altimeter data, J. Phys. Oceanogr., 42 (6), 973-990, http://dx.doi.org/10.1175/JPO-D-11-0159.1.

Rixen M., Beckers J., Levitus S., Antonov J., Boyer T., Maillard C., Fichaut M., Balopoulos E., Iona S., Dooley H., Garcia M., Manca B., Giorgetti A., Manzella G., Mikhailov N., Pinardi N., Zavatarelli M., 2005, The Western Mediterranean Deep Water: a proxy for climate change, Geophys. Res. Lett., 32 (12), L12608, http://dx.doi.org/10.1029/2005GL022702.

Riahi K., Gruebler A., Nakicenovic N., 2007, Scenarios of long-term socio-economic and environmental development under climate stabilization, Technol. Forecast Soc., 74 (4), 887-935, http://dx.doi.org/10.1016/j.techfore.2006.05.026.

Shaltout M., El Gindy A., Omstedt A., 2013, Recent climate trends and future scenarios along the Egyptian Mediterranean coast, Geofizika, 32 (1), (in press).

Shaltout M., Omstedt A., 2012, Calculating the water and heat balances of the Eastern Mediterranean basin using ocean modeling and available meteorological, hydrological and ocean data, Oceanologia, 54(2), 199-232, http://dx.doi.org/10.5697/oc.54-2.199.

Skliris N., Sofianos S., Gkanasos A., Axaopoulos P., Mantziafou A., Vervatis V., 2011, Long-term sea surface temperature variability in the Aegean Sea, Adv. Oceanogr. Limnol., 2 (2), 125-139, http://dx.doi.org/10.1080/19475721.2011. 601325

Skliris N., Sofianos S., Gkanasos A., Mantziafou A., Vervatis V., Axaopoulos P., Lascaratos A., 2012, Decadal scale variability of sea surface temperature in the Mediterranean Sea in relation to atmospheric variability, Ocean Dynam., 62 (1), 13-30, http://dx.doi.org/10.1007/s10236-011-0493-5.

Somot S., Sevault F., Déqué M., 2006, Transient climate change scenario simulation of the Mediterranean Sea for the twenty-first century using a high-resolution 
ocean circulation model, Clim. Dynam., 27 (7-8), 851-879, http://dx.doi.org/ 10.1007/s00382-006-0167-z.

Taylor K., Stouffer R., Meehl G., 2012, An overview of CMIP5 and the experiment design, BAMS, 93 (4), 485-498, http://dx.doi.org/10.1175/ BAMS-D-11-00094.1.

Tsimplis M., Rixen M., 2002, Sea level in the Mediterranean: the contribution of temperature and salinity changes, Geophys. Res. Lett., 29 (23), 2136, 4 pp., http://dx.doi.org/10.1029/2002GL015870.

Trenberth K.E., Large W. G., Olson J. G., 1990, The mean annual cycle in global ocean wind stress, J. Phys. Oceanogr., 20 (11), 1742-1760, http://dx.doi.org/ 10.1175/1520-0485(1990)020<1742:TMACIG $>2.0$. CO;2.

Van Vuuren D., Den Elzen M., Lucas P., Eickhout B., Strengers B., Van Ruijven B., Wonink S., Van Houdt R., 2007, Stabilizing greenhouse gas concentrations at low levels: an assessment of reduction strategies and costs, Climatic Change, 81 (2), 119-159, http://dx.doi.org/10.1007/s10584-006-9172-9.

Vilibić I., Grbec B., Supić N., 2004, Dense water generation in the north Adriatic in 1999 and its recirculation along the Jabuka Pit, Deep-Sea Res. Pt. I, 51 (11), 1457-1474, http://dx.doi.org/10.1016/j.dsr.2004.07.012.

Zervakis V., Georgopoulos D., Drakopoulos P., 2000, The role of the North Aegean in triggering the recent Eastern Mediterranean climatic changes, J. Geophys. Res., 105 (C11), 103-126, http://dx.doi.org/10.1029/2000JC900131. 